\title{
EURO EFFECTS ON THE INTENSIVE AND EXTENSIVE MARGINS OF TRADE
}

\author{
HARRY FLAM \\ HÅKAN NORDSTRÖM \\ CESIFO WORKING PAPER NO. 1881 \\ CATEgORY 7: TRAde Policy \\ DECEMBER 2006
}

An electronic version of the paper may be downloaded

- from the SSRN website:

- from the RePEc website:

- from the CESifo website:

www.SSRN.com

www.RePEc.org

www.CESifo-group.de 


\title{
EURO EFFECTS ON THE INTENSIVE AND EXTENSIVE MARGINS OF TRADE
}

\begin{abstract}
We estimate that the euro has increased trade within the eurozone by about 26 per cent and trade between the eurozone and outsiders by about 12 per cent on average for the years 20022005 compared to 1995-1998. The percentage increases were smaller for products that were exported every year during the sample period than for products that were not, indicating significant and substantial effects on the extensive margin of trade. The euro effects were concentrated to semi-finished and finished products, in particular to industries with highly processed products such as pharmaceuticals and machinery.
\end{abstract}

JEL Code: F1.

Harry Flam

Institute for International Economic Studies

Stockholm University

10691 Stockholm

Sweden

harry.flam@iies.su.se
Håkan Nordström

Swedish Board of Trade

Sweden

hakan.nordstrom@kommers.se

December, 2006

Financial support from Handelsbankens forskningsstiftelser is gratefully acknowledged. 


\section{Introduction}

Eleven member states of the European Union entered into a currency union on January 1, 1999. ${ }^{1}$ The rates at which their national currencies could be exchanged with one another and with the new, common currency - the euro - were irrevocably fixed and the authority to conduct a common monetary policy was assumed by the European Central Bank. A twelfth member of the European Union, Greece, joined the currency union in 2001. The national currencies were replaced as units of accounts by the euro in the beginning of 2002.

Adoption of a common currency reduced trade costs between currency union member countries by eliminating the need to engage resources in handling currency exchange and hedging. It also reduced nominal exchange rate uncertainty, which affects decisions on resource allocation, particularly decisions about trade and foreign direct investment.

The effect of nominal exchange rate uncertainty on trade has been estimated by a great number of studies, mostly in the 1980's and early 1990's. The consensus conclusion is that nominal (and real) exchange rate uncertainty has very small or no effects on trade, see the survey by McKenzie (1999) and the ambitious study by IMF (2004). More recently - and induced by the formation of the European currency union - there has been a proliferation of studies that estimate the trade effects of complete elimination of nominal exchange rate uncertainty, i.e. of currency unions, employing the gravity model of bilateral trade. The seminal study by Rose (2000) using pooled cross-section data for other currency unions estimated that a common currency raises trade by 235 per cent. A later study by Rose (2001) using panel data that include the formation and dissolution of currency unions since 1948 arrived at even higher estimates. As data have been accumulating, a growing number of studies have estimated the trade effects of the currency union directly. Estimates range anywhere from 4 to 30 per cent and more.

The recent currency union literature has been surveyed and critically examined by Baldwin (2006). He argues that estimates based largely on non-European data are driven

\footnotetext{
${ }^{1}$ We will use the term "currency union” to denote what in official European Union language is called the third stage of the European Monetary Union, EMU. It is common to use EMU to mean the currency union, but all European Union member states participate in the first, some in the second stages of the EMU and a subset of 12 countries also participate in the third stage, the currency union.
} 
by countries with peculiar characteristics ("very small, very poor and very open”), are fraught with methodological deficiencies and cannot be used to infer effects of the European currency union. He also finds that most studies that directly estimate European currency union are deficient in a number of ways.

The present study updates our earlier study (Flam and Nordström, 2003) and extends it by estimating effects on the intensive and extensive margins of trade. In contrast to most other studies, we explain one-way trade flows between country pairs, not two-way bilateral trade. (We will use the terms one-way trade flows and exports interchangeably. Exports are of course only one side of the coin.) By using one-way trade flows, we are able to differentiate between effects on trade flows from currency union members to non-members from effects on trade flows in the opposite direction. Fixed costs are an important feature of exporting in the noted trade model by Melitz (2003) and in empirical work by Roberts and Tybout (1997) and others. We expect that the presence of such fixed costs leads to increases in the level of existing trade - the intensive margin - as well as new trade - the extensive margin - when national currencies are replaced by a common currency, as in the model by Baldwin and Taglioni (2004). We attempt to determine whether the European currency union has affected the extensive margin by estimating effects on the number of product categories traded at a high level of disaggregation (the six-digit level of the Harmonized System). We furthermore attempt to decompose the total effect into effects on the internal and external margins. ${ }^{2}$ Finally, we provide estimates of currency union effects for different stages of processing and for trade at the industry level.

\section{Currency union effects in the unconditioned trade data}

Our sample of countries consists of 20 countries that are broadly similar in terms of economic development. Eleven countries entered the currency union in 1999: Austria, Belgium, Finland, France, Germany, Ireland, Italy, Luxembourg, Netherlands, Portugal and Spain. Belgium and Luxembourg were treated as a single entity in trade statistics until 1998, which leaves us with ten currency union members in the sample. Greece

\footnotetext{
${ }^{2}$ At the time of finishing this paper, we received "Euros and zeros: The common currency effect on trade in new goods” by Richard E. Baldwin and Virginia Di Nino. Their paper contains estimates of euro effects on the extensive margin on trade, using a different method.
} 
entered the currency union in 2001, but is not included because of potential problems in controlling for its late entry. The ten countries in our sample that are not members of the currency union are: Australia, Canada, Denmark, Japan, New Zealand, Norway, Sweden, Switzerland, United Kingdom and United States.

Figure 1 shows indexed time series for exports in constant prices for the period 1995-2005. (For reasons to be explained below, trade in energy raw materials and products are not included.) We differentiate between three categories: (1) exports between currency union members, (2) exports from members to non-members, and (3) exports from non-members to members, all relative to trade between the 10 OECD countries in the sample that are not members of the currency union. The indices are unweighted averages of exports in each category. Thus, they are graphical representations of unconditioned panel data.

Figure 1 Total real exports relative to benchmark of 10 OECD countries

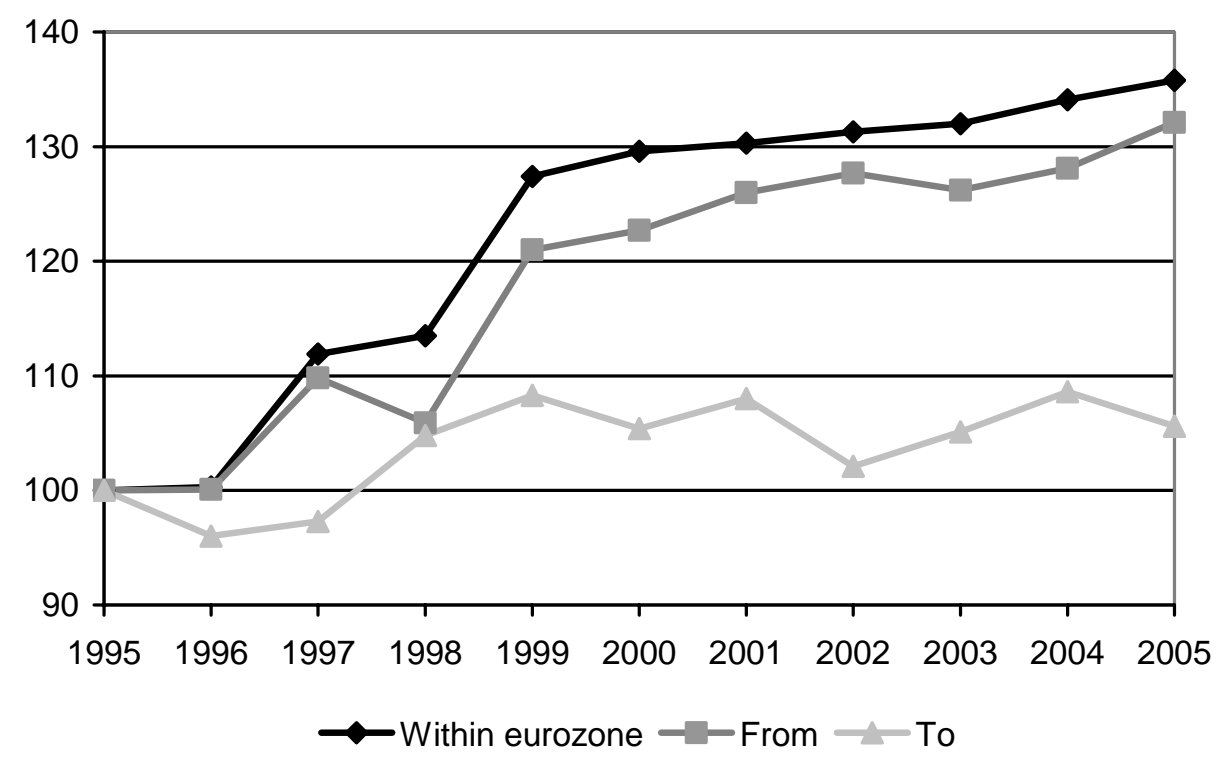

Currency union effects seem to be present for exports within the currency union and from currency union countries to outside countries. There seems to be no effect on 
exports from outside to currency union countries. We need of course to control for other factors that affect trade to be able to determine if currency union effects really are present and how large they are. As will be seen, eyeball econometrics can only take us part of the way.

\section{The gravity model and data sources}

The gravity model has been used extensively to explain bilateral trade. It can be derived from the Ricardian model with a continuum of goods, the Heckscher-Ohlin model with more goods than factors and from the Chamberlin-Heckscher-Ohlin model with monopolistic competition and increasing returns to scale. See Anderson (1979), Deardorff (1998) and Helpman and Krugman (1985) respectively. It can also be derived from an aggregate expenditure function as in Baldwin (2006).

The gravity model states that exports from country $A$ to country $B$ is a function of the product of country $A$ and $B$ 's GDP divided by the cost of exporting from $A$ to $B$. This means that exports from $A$ to $B$ depend positively on the product of GDP's and negatively on the trade cost. Anderson and van Wincoop (2001) have demonstrated that the relevant trade cost is the cost of exporting from $A$ to $B$ relative to the cost of exporting from $A$ 's competitors to $B$.

The trade cost is measured by geographical distance plus many other factors, such as border contiguity, shared language and trade policies. In our specification of the gravity model, we let bilateral fixed effects capture all time invariant factors affecting one-way bilateral trade flows that are not explicitly controlled for. The effects when both the exporter and the importer, only the exporter or only the importer participate in the currency union are estimated by the use of dummy variables. The effects of participation in the Single Market by the exporter, importer or both are controlled for in an analogous manner.

In most applications of the gravity model, the dependent variable is two-way and not one-way bilateral trade. If the dependent variable is two-way trade and trade is balanced, it may be of little consequence not to include the bilateral real exchange rate as an explanatory variable; a change in the real exchange rate will result in offsetting changes in exports and imports. However, real exchange rates with third countries should 
be included (but never are when bilateral real exchange are excluded). If the dependent variable is one-way trade, the volume of trade will depend on the bilateral real exchange rate as well as the real exchange rates between competing exporters and the importing country. We include real exchange rates among the independent variables and use export shares as weights to construct the average real exchange rate between competing exporters and the importing country. When currency union effects are estimated at the industry level, the relevant industry level export shares are used.

The exporter's GDP is a measure of export supply capacity and the importer's GDP is a measure of import demand. Consideration should also be taken of cyclical variation in the elasticity of export supply and import demand, particularly when the sample period is relatively short as here. The export supply elasticity tends to be high when capacity utilization is low in the exporting country and the import elasticity to be high when capacity utilization is high in the importing country. We measure capacity utilization by the deviation from the trend of GDP.

The common presumption that exchange rate volatility affects trade negatively has - as mentioned - little or no support in empirical research. We have not included nominal exchange rate volatility as an explanatory variable in the regressions reported here after finding that contemporaneous and lagged nominal exchange rate volatility have insignificant effects at the 5 per cent level.

Table 1 lists explanatory variables that appear in tables. Not listed are controls for common year effects and for participation in the Single Market by the exporter, importer or both. Data on GDP in constant prices expressed in U.S. dollars were taken from the OECD database. Real exchange rates were calculated as the ratio of national producer price indices converted into U.S. dollars at current exchange rates with data taken from the IMF. Trade data in current U.S. dollars were taken from the UN Comtrade database accessed from the WITS portal. They were deflated using national producer price indices converted into U.S. dollars at current exchange rates. ${ }^{3}$

\footnotetext{
${ }^{3}$ Data on Portugal's trade in 2005 were not yet available.
} 


\begin{tabular}{|c|c|}
\hline & Dummy variables for \\
\hline EZ11p1 & exports within eurozone in period 1 (1999-2001) \\
\hline EZ11p2 & exports within eurozone in period 2 (2002-2005) \\
\hline EZ10p1 & exports from eurozone to outside countries in period 1 (1999-2001) \\
\hline EZ10p2 & exports from eurozone to outside countries in period 2 (2002-2005) \\
\hline EZ01p1 & exports to eurozone from outside countries in period 1 (1999-2001) \\
\hline EZ01p2 & exports to eurozone from outside countries in period 2 (2002-2005) \\
\hline EZ11t(year) & exports within eurozone in (year) \\
\hline EZ10t(year) & exports from eurozone to outside countries in (year) \\
\hline \multirow[t]{2}{*}{ EZ01t(year) } & exports to eurozone from outside countries in (year) \\
\hline & Control variables \\
\hline $\ln R G D P x$ & $\log$ of real GDP of exporter \\
\hline InRGDPm & log of real GDP of importer \\
\hline GAPx & deviation from trend growth of exporter \\
\hline GAPm & deviation from trend growth of importer \\
\hline InREXRxm & log of real exchange rate between exporter and importer \\
\hline InREXRcm & $\begin{array}{l}\text { log of trade-weighted real exchange rate between competing exporters and } \\
\text { importer }\end{array}$ \\
\hline InREXRxm-1 & log of one year lagged real exchange rate between exporter and importer \\
\hline InREXRcm-1 & $\begin{array}{l}\text { log of one year lagged trade-weighted real exchange rate between } \\
\text { competing exporters and importer }\end{array}$ \\
\hline
\end{tabular}

\section{Annual currency union effects}

We first estimate annual currency union effects for aggregate trade. Energy raw materials and products (ISIC Rev. 3 industries 10-12 and 23) are excluded because substantial price effects remain in the deflated trade data, see section 9. We are interested in whether trade levels are significantly higher in 1999 and later for trade where the exporter, importer or both are members of the currency union than trade levels where both the exporter and importer are outsiders. To use terminology borrowed from medical research, we test whether trade that has been given a euro treatment is higher in a given year than trade that 
has not received such treatment. In particular, we are interested in whether levels are higher starting in 1999 and whether a trend or pattern can be seen in the estimates.

Our sample period is 1995-2005. The starting year was chosen for several reasons. First, Austria, Finland and Sweden became members of the EU in 1995. By starting in 1995, we do not have to control for the change in their status. Flam and Nordström (2003) show that estimates of currency union effects are robust to changes in the starting year between 1989 and $1995 .{ }^{4}$ Second, the Single Market officially started in 1993, but was implemented over a period of several years, both before and after 1993. By starting in 1995, we reduce the problem of controlling for Single Market effects. We nevertheless control for such effects in two ways, by controlling for whether the exporter, importer or both participate in the Single Market and by estimating aggregate effects on the full country sample (OECD-20) as well as on the sub-sample of EU countries (EU13). We thereby also control for any additional effect that EU membership may have over and above participation in the Single Market. ${ }^{5}$ Third, starting in 1993, goods that are subjected to customs clearance in a Single Market country on their way to the final destination country are registered as trade both between the source and intermediate country and between the intermediate and final destination country. This has led to large increases in trade for countries with major ports serving trade between Europe and the rest of the world. By beginning the sample period in 1995, we do not need to control for the so-called Rotterdam effect.

Estimates of annual currency union effects on aggregate exports are shown graphically in Figure 2. (See Table A1 for parameter estimates).

\footnotetext{
${ }^{4}$ It should be added that Berger and Nitsch (2005) show that the euro effect on trade is reduced when the sample period is made much longer and becomes dwarfed and made insignificant by the time trend when the sample period is increased to 1948-2003.

${ }^{5}$ Norway is not a member of the EU but participates in the Single Market.
} 
Figure 2 Annual currency union effects

a) Benchmark of 10 OECD countries

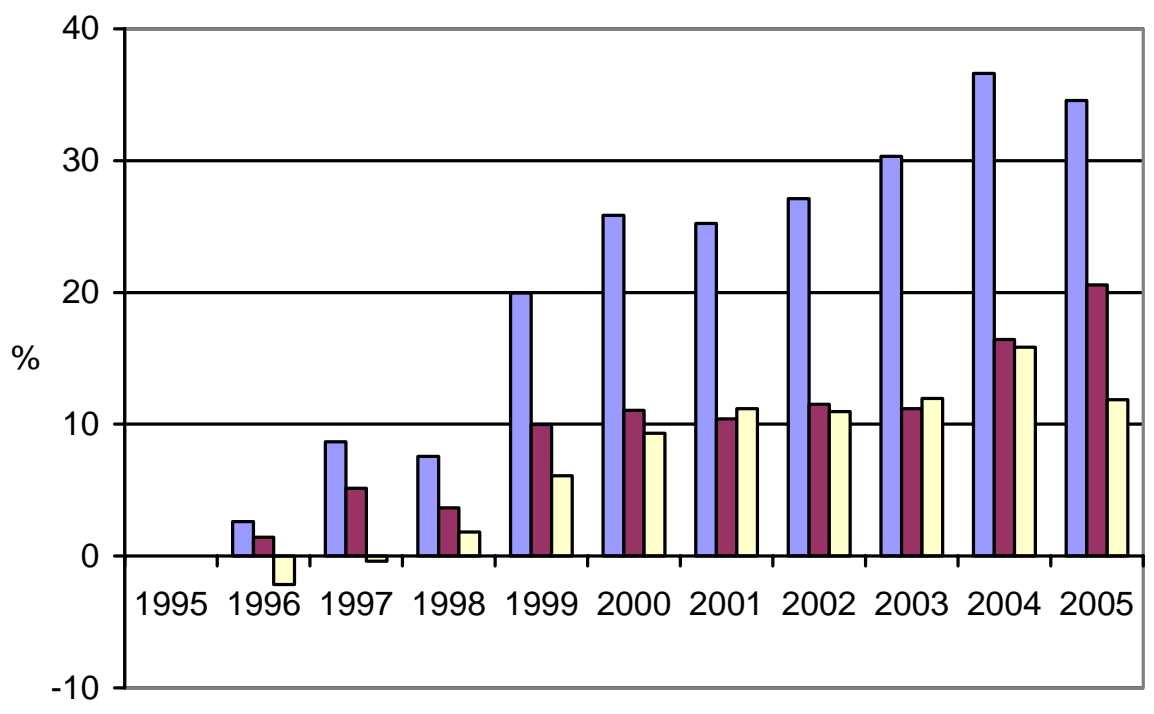

$\square$ Within eurozone $\square$ From $\square$ To

b) Benchmark of $3 \mathrm{EU}$ countries

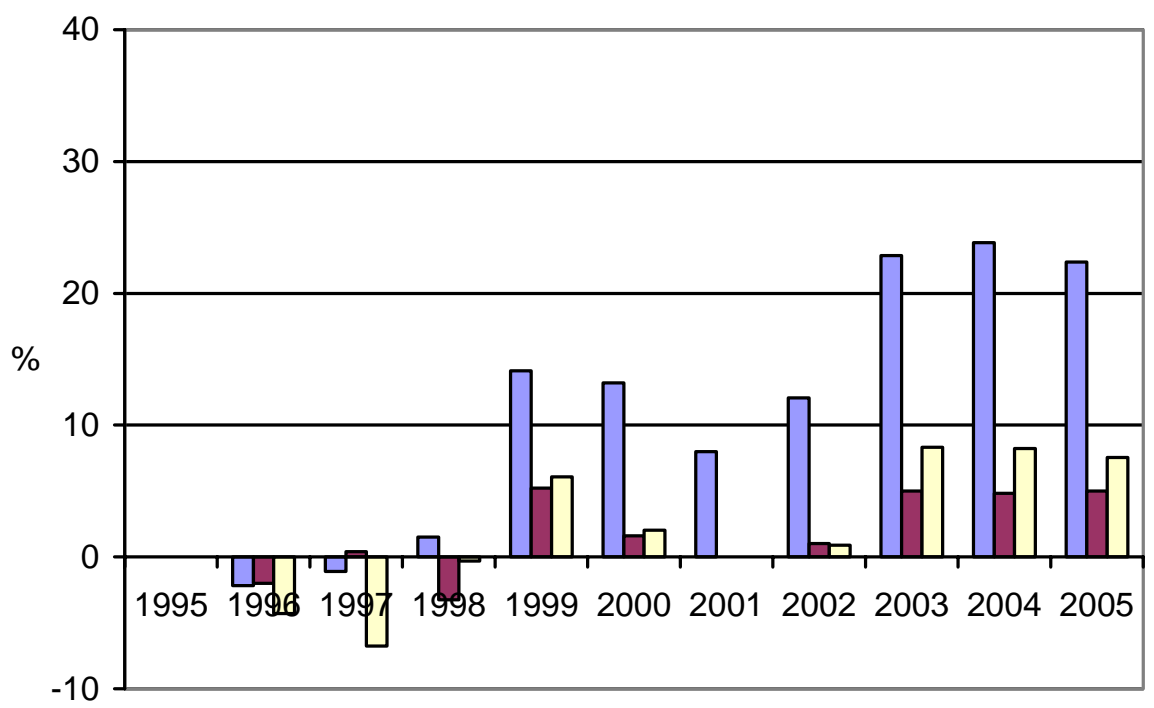

$\square$ Within eurozone $\square$ From $\square$ To 
For the EU-13 sample, significant effects are found only for trade within the currency union and only in 2003-2005. The benchmark is however quite small and therefore relatively susceptible to idiosyncracies; it consists of the six one-way trade flows between Denmark, Sweden and United Kingdom.

A different picture emerges when the benchmark is enlarged to also include seven non-EU countries. As can be seen in table A1, all estimates for exports between currency union members are significant at the 1 per cent level starting in 1999. All estimates for exports from members to non-members are significant at the 1 or 5 per cent level starting in 1999. The estimate for exports from non-members to members is significant at the 10 per cent level in 2000 and at the 1 or 5 per cent levels thereafter.

We conclude that the estimates for the larger country sample of 20 OECD countries - with a larger set of benchmark trade flows - clearly indicate a break in 1999 or 2000. The estimates for the smaller country sample of 13 EU countries - with a more limited benchmark set of trade flows - are not significant in the first years of the currency union, but Figure 2 (b) gives a clear impression of a higher level of trade within the currency union starting already in 1999.

Table A2 presents F-values for tests of differences for all pairs of annual currency union estimates and for both country samples. Panel (a) shows that trade between currency union members are significantly higher at the 1 per cent confidence level for all years in the period 1999-2004 compared to 1995-1998 for the OECD-20 country sample. It also shows that the currency union effect is increasing; the estimates for 2003-2005 are mostly significantly higher than the estimates for 1999-2002. The pattern of significantly higher estimates for the currency union period is evident also for exports to and from the eurozone, but not as clearly. Panel (b) for the EU-13 country sample shows that trade between currency union countries is significantly higher in most years in 1999-2004 compared to 1995-1998. However, no such pattern can be seen for exports to and from the eurozone.

We conclude that the estimates in Table A1 and tests in Table A2 provide strong support for the existence of significant currency union effects. First, estimates for exports between currency union members become significant in 1999. It is not surprising that effects can be seen already in 1999. The most important decisions on the currency union 
were taken by the European Council in May of 1998, when it decided which countries would be allowed to join and fixed the exchange rates at which national currencies would be converted into euros on January 1, 1999. Exchange rates were effectively fixed in May, since any changes between May and January could easily be hedged against. Second, post-1999 estimates are mostly significantly different from the pre-1999 estimates. Third, there is a clear tendency that the currency union effects are increasing over time as should be expected.

\section{Average currency union effects}

We next estimate average currency union effects for the years 1999-2001 - which should be considered as a transition period - and for the years 2002-2005 - when the effects should have taken effect more fully. The estimates for each sub-period show by how much treated trade differs from non-treated trade in that period controlling for other factors. This amounts to comparing differences between levels of treated trade between the pre-currency period and levels in the currency union period with the corresponding differences for non-treated trade levels.

Table 2 shows estimated average currency union effects for aggregate trade (excluding energy raw materials and products): 
Table 2 Aggregate currency union effects

OECD-20

EZ11p1

EZ11p2

EZ10p1

EZ10p2

EZ01p1

EZ01p2

InRGDP_i

InRGDP

InREXRij

InREXRkj

InREXRij1

InREXRkj1

Observations

Number of Panel

$\mathrm{R}$-squared

$0.165^{\star \star \star}$
$[0.023]$
$0.232^{\star \star \star}$
$[0.024]$
$0.074^{\star \star \star}$
$[0.020]$

$0.113^{\star \star \star}$

[0.022]

$0.085^{\star \star \star}$

[0.025]

$0.120^{\star \star \star}$

[0.026]

$0.590^{* * *}$

[0.089]

$1.185^{\star \star \star}$

[0.078]

$-0.189^{\star * \star}$

[0.066]

$-0.297^{\star \star \star}$

[0.094]

$-0.605^{\star \star \star}$

[0.067]

$0.392^{\star \star \star}$

[0.091]

4161

380

0.53
EU-13

(18.0\%)

(26.1\%)

$0.114^{\star \star \star}$

[0.032]

$0.187^{\star \star \star} \quad(20.6 \%)$

[0.037]

0.032

[0.033]

0.052

[0.039]

0.053

[0.033]

$0.086^{\star \star}$

[0.040]

$0.603^{\star \star \star}$

[0.117]

$1.198^{\star \star \star}$

[0.104]

$-0.320^{* \star *}$

[0.113]

$-0.161$

[0.153]

$-0.595^{\star * *}$

[0.108]

$0.464^{\star \star *}$

[0.157]

$(5.3 \%)$

$(9.0 \%)$

OLS, robust standard errors in brackets

* significant at $10 \%$; ${ }^{* *}$ significant at $5 \%$; ${ }^{* \star}$ significant at $1 \%$

Country pair fixed effects, controls for deviations from trend GDP and common year effects

Note: Pecentage change $=100^{*}[\exp ($ estimate $)-1]$

As can be seen, average currency union effects are estimated to be large.

Comparing the average for 2002-2005 with the average for 1995-1998, the largest effects are estimated for exports within the eurozone, where the effect is 26 per cent in the 
OECD-20 country sample and 21 per cent in the EU-13 country sample. Substantial effect are estimated also for exports from and to the eurozone. For the OECD-20 sample, the effect is 12 per cent on exports from the eurozone to outsiders and 13 per cent on exports to the eurozone from outsiders. For the EU-13 sample, only one estimate is significant. The significant effect is for exports from outsiders to the eurozone and is 9 per cent.

The results give rise to two questions. First, customs union theory predicts that the elimination of tariffs or other trade barriers between custom union members leads to increased trade between members - trade creation - at the expense of decreased trade between members and non-members - trade diversion. The reason is that imports from outside countries are replaced by imports from custom union member countries, since imports from the latter have become relatively cheaper by the elimination of trade barriers within the customs union. Our estimates say that the currency union has led to trade creation all around, between members as well as between members and nonmembers. Second, the formation of the currency union has surprisingly large effects, considering that the resource costs of currency exchange and hedging against changes in nominal exchange rates are small, probably not greater than a fraction of one per cent (Calmfors et al, 1997), and considering that the empirical research finds that nominal exchange rate uncertainty has small or no effects on trade.

The unexpected increase in exports from non-members to members could be explained by the existence of fixed costs in exporting. Assume that exporting requires local sales, marketing and distribution facilities. Assume further that the low trade costs between countries forming the Single Market in combination with economies of scale make it profitable for outside exporters to have such facilities in just one country inside the Single Market and to incur the costs of shipping products to other countries within the Single Market through that country. Given these assumptions, outside exporters may benefit from the common currency to almost the same extent as exporters inside the Single Market. In addition, the reduction in trade costs caused by the common currency may make it profitable to incur the fixed costs of exporting and lead to new exports to currency union members from outside countries. 
The increase in exports from members of the currency union to non-members could be explained by lower cost of inputs for exporters. The common currency has lowered the cost of purchasing inputs from other countries belonging to the currency union and thereby made producers in the currency union more competitive. Yi (2003) shows that if the production process involves several stages located in different countries and the shipping of intermediate inputs across national borders, small trade costs can add up to a considerable share of the final cost.

The surprisingly large currency union effects indicate that reduction of nominal exchange rate volatility on one hand and completely eliminating it by forming a currency union on the other are qualitatively different phenomena. It could be that the effect of reducing nominal exchange rate uncertainty is highly non-linear; the difference in uncertainty between even very small exchange rate volatility under a regime of flexible exchange rates and no nominal exchange rate volatility under a common currency is probably great in the minds of economic decision makers.

Most of the empirical research on the trade effects of exchange rate uncertainty has dealt with changes at relatively high frequencies, month-to-month, quarter-to-quarter or year-to-year. Exchange rate uncertainty within a year can easily be hedged against at low cost, but longer term uncertainty is much more costly or impossible to hedge against. If exporting decisions involve fixed costs and have time horizons of several years, exchange rate uncertainty could have much greater effects than generally found in the empirical research. Relatively few studies have estimated the effects of exchange rate changes at low frequencies, but they tend to find significant negative trade effects (McKenzie, 1999).

It should be noted that almost all of the GDP and real exchange rate variables in Table 4 have expected signs and that most are highly significant. The elasticity of exports with respect to the importing country's GDP is about 1.2, which is consistent with the trend increase in the ratio of trade to GDP. The deviation from trend GDP in the importing country has the expected positive sign and is significant (not shown), indicating that imports depend positively on domestic capacity in a cyclical fashion. The exporting country’s deviation from trend GDP has no significant effect however. Real exchange rates mostly have expected signs and are significant. The exception is the 
contemporaneous effect of competitors' real exchange rates in the destination country, which is estimated to be negative instead of positive.

\section{Robustness checks}

Table A3 shows how robust the currency union estimates are to dropping controls for GDP and real exchange rates. Estimates tend to increase as controls are dropped, but remain highly significant. Note that contemporaneous real exchange rates pick up significant effects in dropped lagged real exchange rates and that $\mathrm{R}^{2}$ is unaffected by dropping lagged real exchange rates.

Tables A4 and A5 report how robust estimates are to dropping individual countries in the OECD-20 and EU-13 country samples respectively. The estimates are remarkably constant in size and significance in the case of most countries, with two notable exceptions. Dropping Denmark raises all currency union effects substantially, which indicates that the introduction of the euro caused Denmark to increase its trade with countries outside the currency union and decrease its trade with currency union countries in relative terms. Dropping the United Kingdom lowers the currency union effects, which indicates that the euro caused the United Kingdom to increase its trade with currency union members and decrease its trade with other outside countries .

It must be kept in mind that Denmark and United Kingdom together with Sweden make up the benchmark in the EU-13 estimates. Dropping one of them reduces the benchmark number of export flows from six to only two and make the estimates much more dependent on any idiosyncratic effects in the remaining benchmark trade flows. For this reason, we have more confidence in the estimates with the larger benchmark of 10 OECD countries.

\section{Currency union effects on the intensive and extensive margins of trade}

The estimated currency union effects can in principle be due to increases on the intensive or extensive margins of trade or both. An increase on the intensive margin of trade refers to increased exports of products already being exported and an increase on the extensive margin refers to exports of products that have not been exported before. Lower trade costs make foreign goods more competitive relative to domestic goods and should 
therefore lead to increases in existing trade but also to new trade to the extent that it becomes profitable and can cover start-up and fixed costs of exporting.

In order to differentiate between the internal and external margins of trade we make use of highly disaggregated trade data, the six-digit level of the Harmonized System (HS). This means that the dataset becomes very large. We have 380 bilateral oneway trade relations, the sample period consists of 11 years and the number of statistical product categories at the six-digit level is about 5 015, which yields a dataset of nearly 21 million observations, including zeros.

The number of statistical HS-6 categories that are exported over time can give us a first indication of euro effects on the extensive margin of trade. We have calculated the number of exported six-digit level statistical product categories during the sample period for each bilateral one-way trade relation. Panels (a) and (b) of figure 3 show indexed time series for the number of product categories in trade within, from and to the eurozone relative to the 10 outside OECD countries and 3 outside EU countries respectively. A strong business cycle element is apparent in the raw data for the number of products exported within and from the eurozone - the number peaks at the height of the business cycle in the year 2000 and then drops - but there is also a rising trend. The business cycle element is probably due to the fact imports are needed to satisfy demand when capacity utilization is high at the peak of the business cycle. 
Figure 3 Number of exported HS-6 product categories

(a) Relative to benchmark with 10 OECD countries

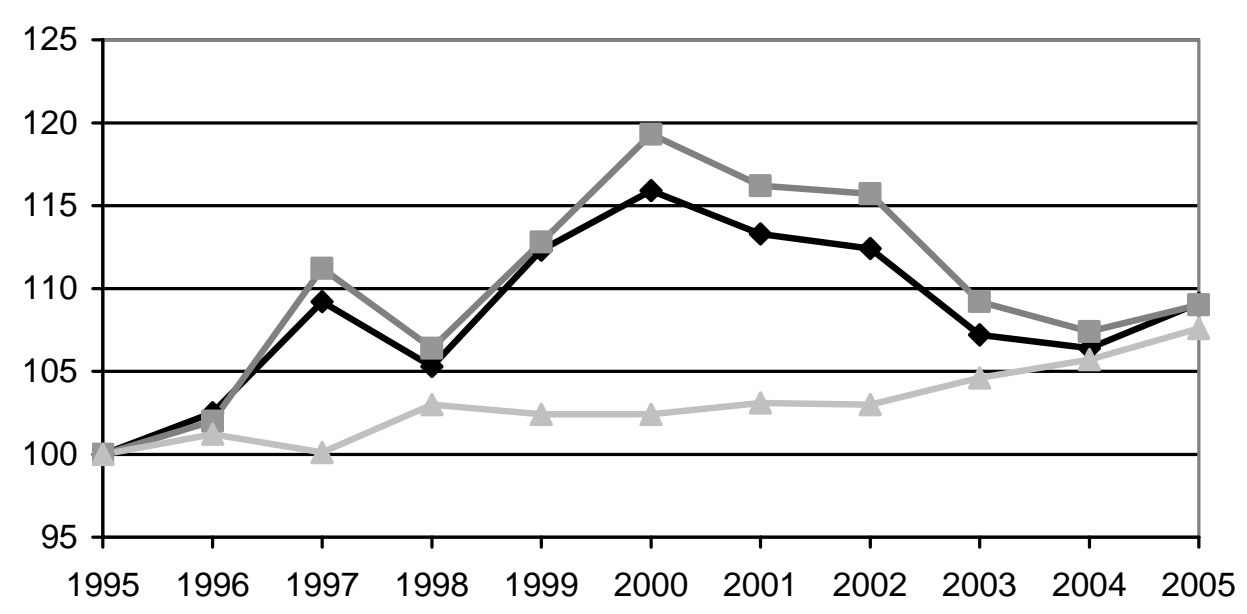

(b) Relative to benchmark of 3 EU countries

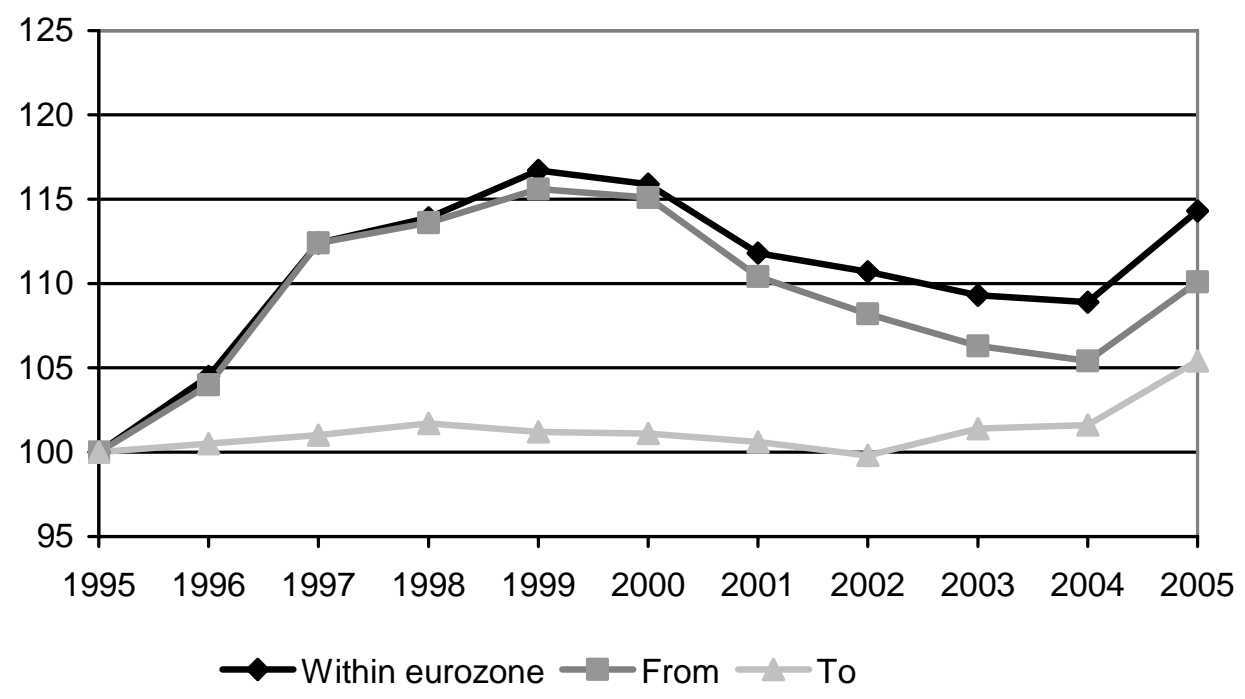

We have estimated euro effects on the number of exported product categories, employing the same specification of the gravity equation. The results are reported in Table 3. 
Table 3 Currency union effects on the number of exported HS-6 product categories

\begin{tabular}{|c|c|c|c|c|}
\hline \multirow[b]{2}{*}{ EZ11p1 } & \multicolumn{2}{|c|}{20 OECD countries } & \multicolumn{2}{|c|}{13 EU countries } \\
\hline & $\begin{array}{l}0.031 \text { *** } \\
{[0.009]}\end{array}$ & $(3.1 \%)$ & $\begin{array}{l}-0.003 \\
{[0.009]}\end{array}$ & $(-0.3 \%)$ \\
\hline EZ11p2 & $\begin{array}{l}0.056^{\star \star \star} \\
{[0.011]}\end{array}$ & $(5.8 \%)$ & $\begin{array}{l}0.006 \\
{[0.012]}\end{array}$ & $(0.6 \%)$ \\
\hline EZ10p1 & $\begin{array}{l}0.031 \text { *** } \\
{[0.008]}\end{array}$ & $(3.1 \%)$ & $\begin{array}{l}-0.001 \\
{[0.010]}\end{array}$ & $(-0.1 \%)$ \\
\hline EZ10p2 & $\begin{array}{l}0.040^{\star \star \star} \\
{[0.009]}\end{array}$ & (4.1\%) & $\begin{array}{l}-0.013 \\
{[0.012]}\end{array}$ & $(-1.3 \%)$ \\
\hline EZ01p1 & $\begin{array}{l}0.014 \\
{[0.011]}\end{array}$ & $(1.4 \%)$ & $\begin{array}{l}-0.007 \\
{[0.010]}\end{array}$ & $(-0.7 \%)$ \\
\hline EZ01p2 & $\begin{array}{l}0.038^{\star \star \star} \\
{[0.013]}\end{array}$ & $(3.9 \%)$ & $\begin{array}{l}0.004 \\
{[0.013]}\end{array}$ & $(0.4 \%)$ \\
\hline InRGDPx & $\begin{array}{l}0.237^{* \star *} \\
{[0.035]}\end{array}$ & & $\begin{array}{l}0.162^{\star * *} \\
{[0.029]}\end{array}$ & \\
\hline InRGDPm & $\begin{array}{l}0.412^{\star \star \star} \\
{[0.038]}\end{array}$ & & $\begin{array}{l}0.405^{\star \star \star} \\
{[0.038]}\end{array}$ & \\
\hline InREXRxm & $\begin{array}{l}-0.764^{\star \star \star} \\
{[0.028]}\end{array}$ & & $\begin{array}{l}-0.826^{\star * \star} \\
{[0.036]}\end{array}$ & \\
\hline InREXRcm & $\begin{array}{l}0.661^{\star \star \star} \\
{[0.042]}\end{array}$ & & $\begin{array}{l}0.847^{\star \star \star} \\
{[0.055]}\end{array}$ & \\
\hline InREXRxm-1 & $\begin{array}{l}-0.120^{\star \star \star} \\
{[0.026]}\end{array}$ & & $\begin{array}{l}-0.211^{\star \star \star} \\
{[0.032]}\end{array}$ & \\
\hline InREXRcm-1 & $\begin{array}{l}0.120^{\star \star \star} \\
{[0.039]}\end{array}$ & & $\begin{array}{l}0.158^{\star \star \star} \\
{[0.050]}\end{array}$ & \\
\hline Observations & 4161 & & 1704 & \\
\hline Panels & 380 & & 156 & \\
\hline R-squared & 0.74 & & 0.91 & \\
\hline $\begin{array}{l}\text { OLS, robust st } \\
\text { * significant at }\end{array}$ & $\begin{array}{l}\text { brackets } \\
\text { int at 5\%; * }\end{array}$ & * signific & & \\
\hline
\end{tabular}

Significant euro effects are found only for the OECD-20 country sample. The euro is estimated to have increased the number of exported HS-6 products within the eurozone by about 6 per cent and exports to and from the eurozone by about 4 per cent.

The number of exported HS-6 product categories is of course only an approximation of the extensive margin of trade. It is the net of new and discontinued 
exports and each category holds products that sometimes are very imperfect substitutes. Also, we cannot gauge the quantitative importance of external relative to internal margin effects based on our estimates for total exports and for the number of exported products, since the estimates are based on different units of account. It is probably the case that the value per product category of new exports is considerably smaller on average than that of existing exports. It is therefore not sufficient to count the number of exported products on the respective margin to assess the importance of effects on the intensive relative to the extensive margin.

Instead, we use a different approach. We define the intensive margin to consist of HS-6 categories that are exported in each and every year in a given bilateral one-way trade relation. There are approximately 1.9 million such relations. The difference between total exports and these "core" exports are defined as exports on the extensive margin of trade. The extensive margin consists of statistical product categories where no exports were registered in at least one of the years in our eleven year sample period. Some statistical product categories cease to be exported after a certain year, some are exported intermittently during the sample period, and some are exported every year starting in some year after 1995. Only the latter correspond to the theoretical concept of external margin. The value of extensive margin exports defined this way as a share of total exports amount to 10.6 per cent of exports within the eurozone, 15.5 per cent of export from the eurozone, 17.7 per cent of exports to the eurozone and 17.4 per cent of exports between outside countries on average for the pre-currency union years, 1995-1998. Ideally, the share should be zero in the starting year.

Figure 4 presents raw data on total exports and on intensive and extensive margin exports as defined above. The series are indexed and expressed relative to the benchmark of 10 OECD countries. As can be seen, intensive margin exports exhibit the same time pattern as total exports, with a marked increase in intensive margin exports within the eurozone and from the eurozone to outside countries during the euro period. The upward trends are stronger for extensive than intensive margin exports and pertain to all categories of exports relative to exports between outside countries. 
Figure 4 Total, intensive and extensive margin exports relative to OECD-10

a) Total exports

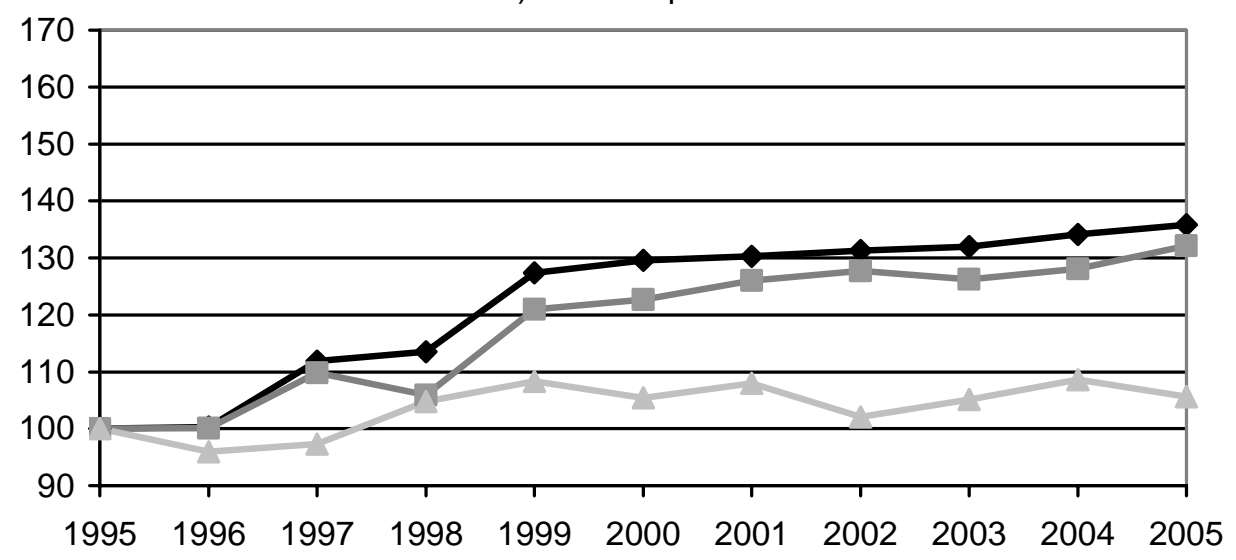

b) Intensive margin

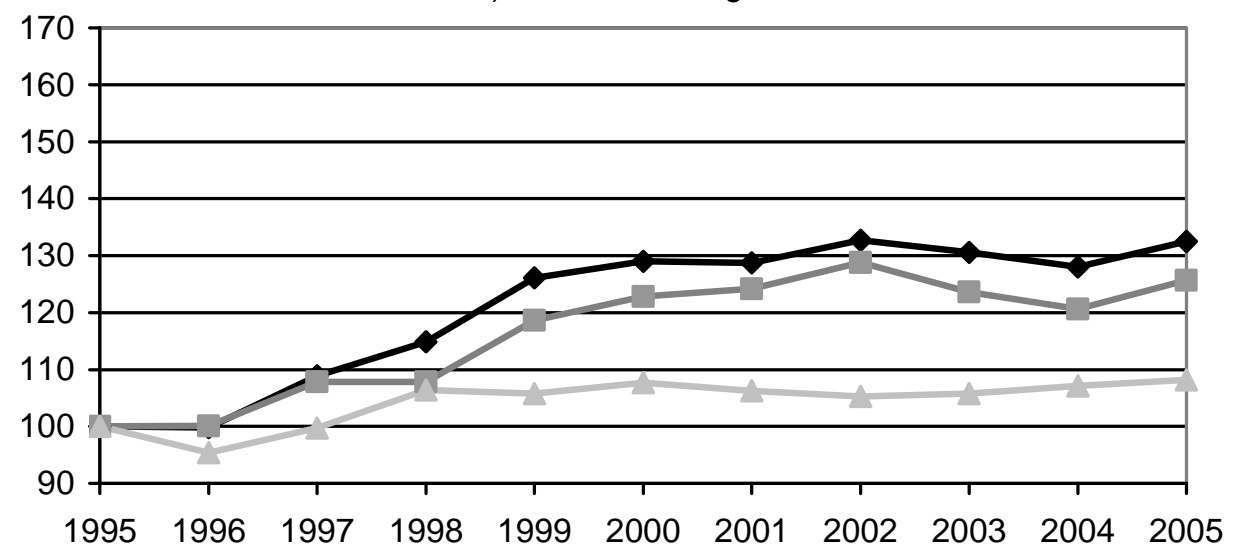

c) Extensive margin

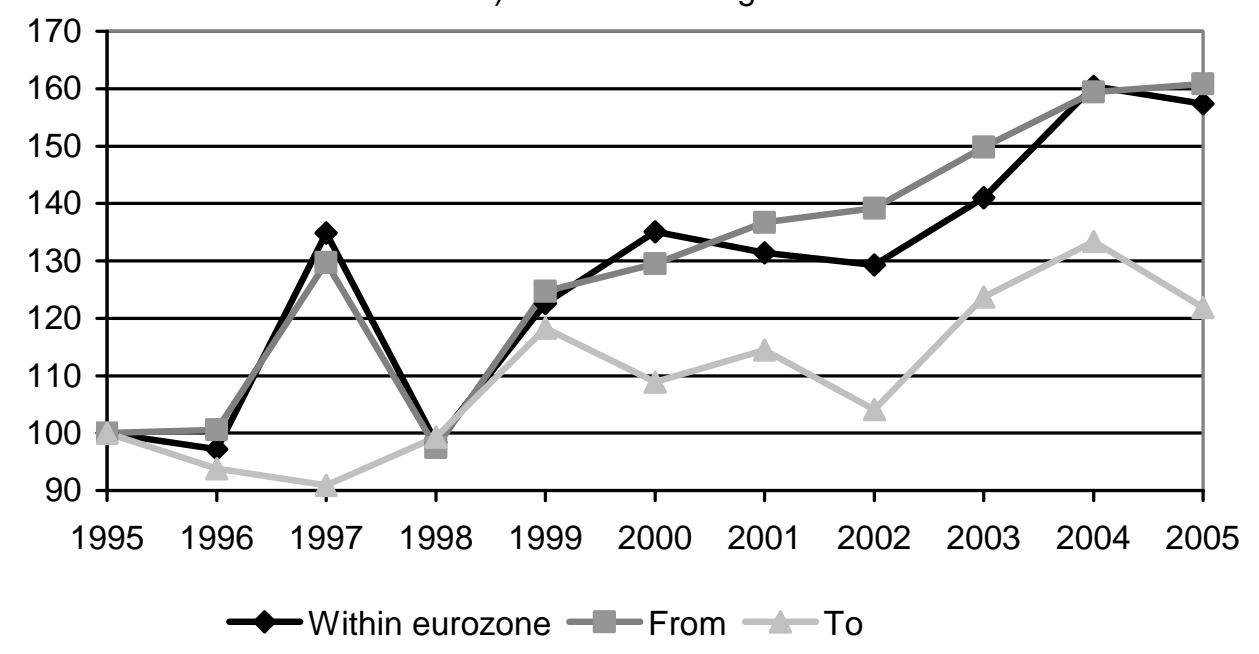


The estimates reported in Table 4 confirm the impression from the raw data that euro effects on the extensive margin are greater (in percentage terms) than on the intensive margin of trade.

Table 4 Currency union effects on the intensive and extensive margins of trade

\begin{tabular}{|c|c|c|c|c|c|c|}
\hline & 20 OECD & countries & & $13 \mathrm{EU}$ co & untries & \\
\hline & Total & $\begin{array}{l}\text { Intensive } \\
\text { margin }\end{array}$ & $\begin{array}{l}\text { Extensive } \\
\text { margin }\end{array}$ & Total & $\begin{array}{l}\text { Intensive } \\
\text { margin }\end{array}$ & $\begin{array}{l}\text { Extensive } \\
\text { Margin }\end{array}$ \\
\hline EZ11p1 & $\begin{array}{l}0.165^{\star \star \star} \\
{[0.023]}\end{array}$ & $\begin{array}{l}0.149 * * \star \\
{[0.021]}\end{array}$ & $\begin{array}{l}0.210^{\star * \star} \\
{[0.059]}\end{array}$ & $\begin{array}{l}0.114^{\star \star *} \\
{[0.032]}\end{array}$ & $\begin{array}{l}0.128^{\star \star \star} \\
{[0.034]}\end{array}$ & $\begin{array}{l}0.061 \\
{[0.083]}\end{array}$ \\
\hline EZ11p2 & $\begin{array}{l}0.232^{\star * \star} \\
{[0.024]}\end{array}$ & $\begin{array}{l}0.201 * \star * \\
{[0.022]}\end{array}$ & $\begin{array}{l}0.324^{\star * *} \\
{[0.057]}\end{array}$ & $\begin{array}{l}0.187^{\star \star \star} \\
{[0.037]}\end{array}$ & $\begin{array}{l}0.184^{\star \star *} \\
{[0.038]}\end{array}$ & $\begin{array}{l}0.215^{\star *} \\
{[0.090]}\end{array}$ \\
\hline EZ10p1 & $\begin{array}{l}0.074^{\star * *} \\
{[0.020]}\end{array}$ & $\begin{array}{l}0.044^{\star \star} \\
{[0.018]}\end{array}$ & $\begin{array}{l}0.146^{\star \star *} \\
{[0.050]}\end{array}$ & $\begin{array}{l}0.032 \\
{[0.033]}\end{array}$ & $\begin{array}{l}0.028 \\
{[0.034]}\end{array}$ & $\begin{array}{l}0.055 \\
{[0.088]}\end{array}$ \\
\hline EZ10p2 & $\begin{array}{l}0.113^{\star * *} \\
{[0.022]}\end{array}$ & $\begin{array}{l}0.072^{\star \star \star} \\
{[0.020]}\end{array}$ & $\begin{array}{l}0.274^{\star * *} \\
{[0.050]}\end{array}$ & $\begin{array}{l}0.052 \\
{[0.039]}\end{array}$ & $\begin{array}{l}0.031 \\
{[0.040]}\end{array}$ & $\begin{array}{l}0.228^{\star *} \\
{[0.097]}\end{array}$ \\
\hline EZ01p1 & $\begin{array}{l}0.085^{\star \star \star *} \\
{[0.025]}\end{array}$ & $\begin{array}{l}0.078^{\star \star \star} \\
{[0.021]}\end{array}$ & $\begin{array}{l}0.129^{\star *} \\
{[0.057]}\end{array}$ & $\begin{array}{l}0.053 \\
{[0.033]}\end{array}$ & $\begin{array}{l}0.070^{* *} \\
{[0.035]}\end{array}$ & $\begin{array}{l}-0.028 \\
{[0.082]}\end{array}$ \\
\hline EZ01p2 & $\begin{array}{l}0.120 * \star \star \\
{[0.026]}\end{array}$ & $\begin{array}{l}0.090^{\star \star \star *} \\
{[0.024]}\end{array}$ & $\begin{array}{l}0.283^{\star \star \star} \\
{[0.054]}\end{array}$ & $\begin{array}{l}0.086^{\star \star} \\
{[0.040]}\end{array}$ & $\begin{array}{l}0.087^{\star \star} \\
{[0.043]}\end{array}$ & $\begin{array}{l}0.117 \\
{[0.090]}\end{array}$ \\
\hline InRGDPx & $\begin{array}{l}0.590^{* \star *} \\
{[0.089]}\end{array}$ & $\begin{array}{l}0.623^{\star \star \star} \\
{[0.090]}\end{array}$ & $\begin{array}{l}0.330^{\star *} \\
{[0.152]}\end{array}$ & $\begin{array}{l}0.603^{\star \star \star} \\
{[0.117]}\end{array}$ & $\begin{array}{l}0.658^{\star \star \star \star} \\
{[0.122]}\end{array}$ & $\begin{array}{l}0.027 \\
{[0.181]}\end{array}$ \\
\hline InRGDPm & $\begin{array}{l}1.185^{\star * *} \\
{[0.078]}\end{array}$ & $\begin{array}{l}1.054 \text { *** } \\
{[0.084]}\end{array}$ & $\begin{array}{l}1.548^{\star \star *} \\
{[0.150]}\end{array}$ & $\begin{array}{l}1.198^{\star \star \star} \\
{[0.104]}\end{array}$ & $\begin{array}{l}0.972^{\star * *} \\
{[0.114]}\end{array}$ & $\begin{array}{l}1.689 * * * \\
{[0.196]}\end{array}$ \\
\hline InREXRxm & $\begin{array}{l}-0.189^{\star \star \star} \\
{[0.066]}\end{array}$ & $\begin{array}{l}-0.164^{\star *} \\
{[0.068]}\end{array}$ & $\begin{array}{l}-0.131 \\
{[0.149]}\end{array}$ & $\begin{array}{l}0.320^{\star \star \star} \\
{[0.113]}\end{array}$ & $\begin{array}{l}-0.287^{\star *} \\
{[0.116]}\end{array}$ & $\begin{array}{l}-0.949 \star \star \star \\
{[0.253]}\end{array}$ \\
\hline InREXRcm & $-0.297^{\star \star \star}$ & $-0.244^{\star \star \star}$ & $-0.357^{\star}$ & -0.161 & $-0.317^{\star *}$ & $0.850^{\star \star}$ \\
\hline InREXRxm-1 & $\begin{array}{l}{[0.094]} \\
-0.605^{\star \star \star} \\
{[0.067]}\end{array}$ & $\begin{array}{l}{[0.091]} \\
-0.673^{\star \star \star} \\
{[0.068]}\end{array}$ & $\begin{array}{l}{[0.212]} \\
-0.772^{\star \star \star} \\
{[0.155]}\end{array}$ & $\begin{array}{l}{[0.153]} \\
0.595^{\star \star \star} \\
{[0.108]}\end{array}$ & $\begin{array}{l}{[0.157]} \\
-0.578^{\star \star \star} \\
{[0.112]}\end{array}$ & $\begin{array}{l}{[0.399]} \\
-0.398^{\star} \\
{[0.241]}\end{array}$ \\
\hline InREXRcm-1 & $\begin{array}{l}0.392^{\star * *} \\
{[0.091]}\end{array}$ & $\begin{array}{l}0.403^{\star \star \star} \\
{[0.091]}\end{array}$ & $\begin{array}{l}0.637^{\star \star *} \\
{[0.221]}\end{array}$ & $\begin{array}{l}0.464^{\star \star \star} \\
{[0.157]}\end{array}$ & $\begin{array}{l}0.419^{\star *} \\
{[0.164]}\end{array}$ & $\begin{array}{l}0.375 \\
{[0.398]}\end{array}$ \\
\hline Observations & 4161 & 4161 & 4161 & 1704 & 1704 & 1704 \\
\hline Panels & 380 & 380 & 380 & 156 & 156 & 156 \\
\hline R-squared & 0.53 & 0.52 & 0.20 & 0.65 & 0.62 & 0.31 \\
\hline
\end{tabular}

OLS, robust standard errors in brackets

Controls for deviations from GDP trend, Single Market participation and common year effects

Country pair fixed effects, controls for deviations from GDP trend, Single Market participation and common year effects 
Practically all euro effects on the intensive and extensive margins of trade for the larger sample of 20 OECD countries are highly significant, but the extensive margin effects are estimated to be up to three times larger than the intensive margin effects. This is not surprising, considering that the extensive margin contains both products that are exported intermittently during the sample period - a "soft" core - and a net increase in the number of products. Solving for the weights that make the intensive and extensive margin estimates add up to the estimates for total trade, we find that the weight is 0.25 for extensive margin exports within the eurozone, 0.20 for exports from the eurozone and 0.15 for exports to the eurozone.

As for the sample of $13 \mathrm{EU}$ countries, only the estimates for exports within the eurozone are significant. Here the weight on the estimate for extensive margin exports is smaller, 0.07 .

\section{Currency union effects at different stages of processing}

The estimated currency union effects are surprisingly large, considering the relatively small resource costs of currency exchange and hedging. We have speculated that switching from flexible nominal exchange rates to fixed rates under a common currency should have much larger effects than reducing nominal exchange rate volatility without a regime change. We have also speculated that the existence of fixed costs in combination with the reduction in trade costs serve to increase trade between currency union members and outside countries.

We may obtain a better understanding of the currency union effects by estimating effects on a disaggregated level, for different stages of processing and different product groups. If our explanations in terms of uncertainty and fixed costs are valid, we should expect effects to be concentrated on highly processed products, which require relatively high fixed costs in the form of distribution and marketing and which typically consist of a great number of inputs that are sourced from several countries, where the same component can cross national borders more than once in the process of production and assembly. 
Figure $5 \mathrm{~A}$ and $\mathrm{B}$ report the indexed time series for raw material, semi-finished and finished exports, respectively, relative to the two benchmarks. The different stages of processing are defined according to the World Trade Organization's MTN (Multilateral Trade Negotiation) classification. The raw data give the impression that euro effects are present for semi-finished products and perhaps for finished products, but not for raw materials. 
Figure $5 \mathrm{~A}$ Exports of raw materials, semi-finished and finished products relative to the benchmark of 10 OECD countries

(a) Raw materials

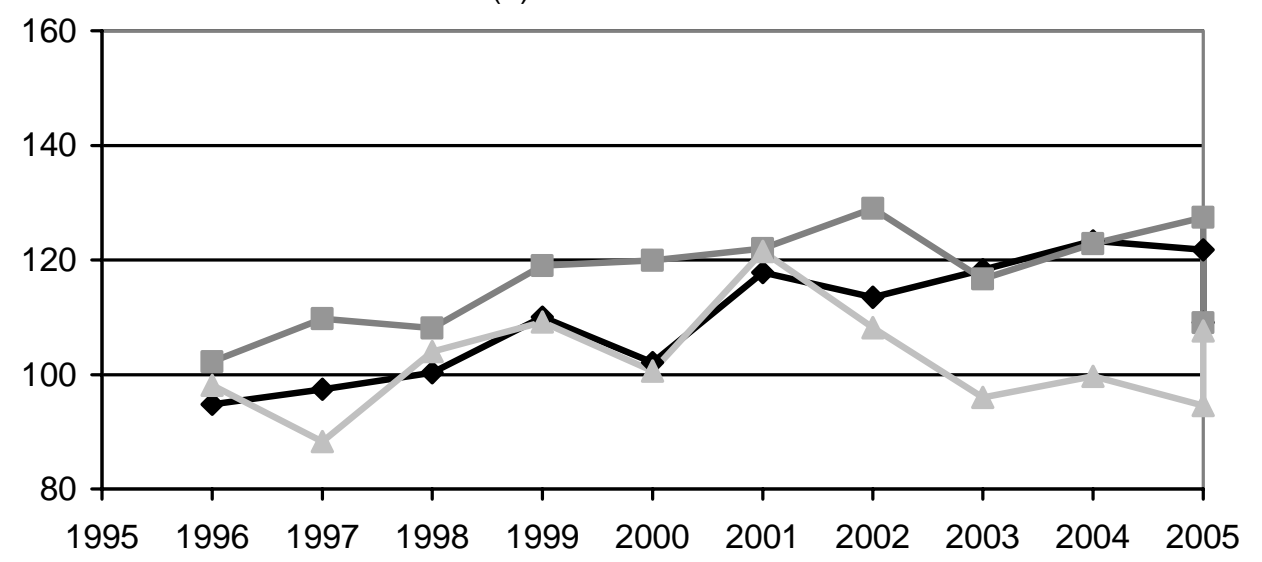

(b) Semi-finished products

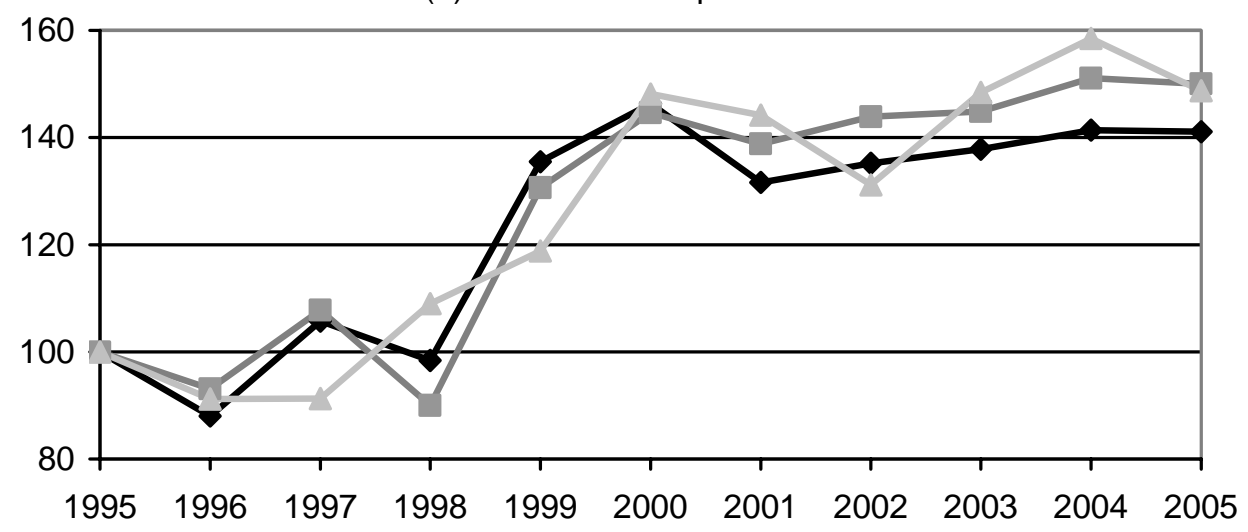

(c) Finished products

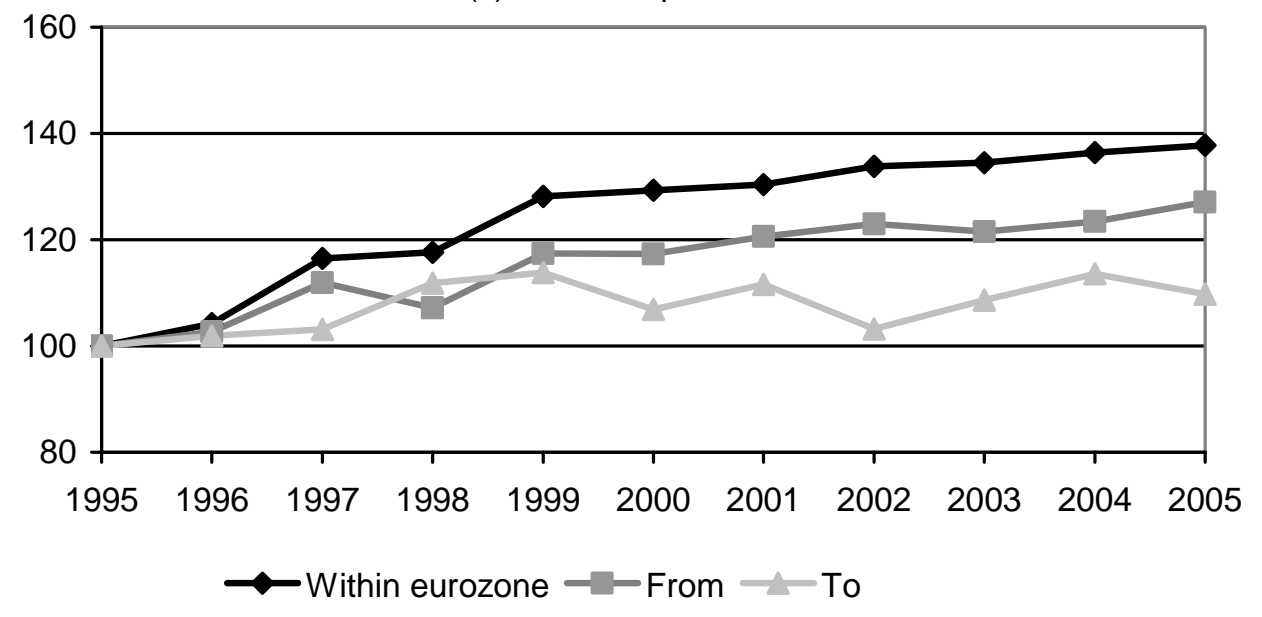


Figure $5 \mathrm{~B}$ Exports of raw materials, semi-finished and finished products relative to the benchmark of 3 EU countries

(a) Raw materials

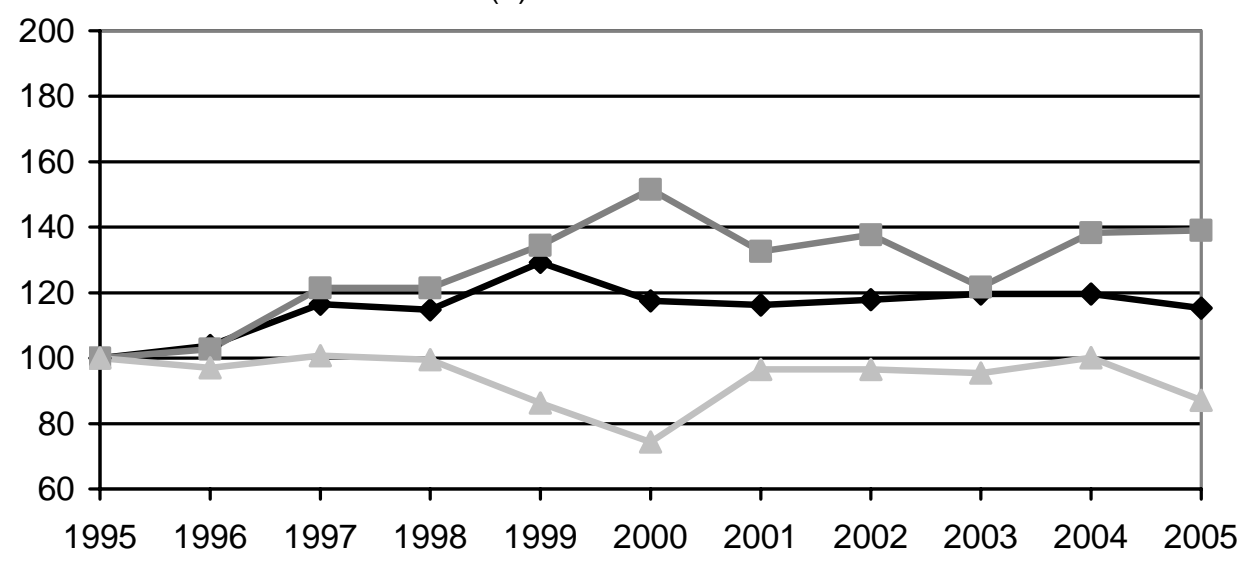

(b) Semi-finished products

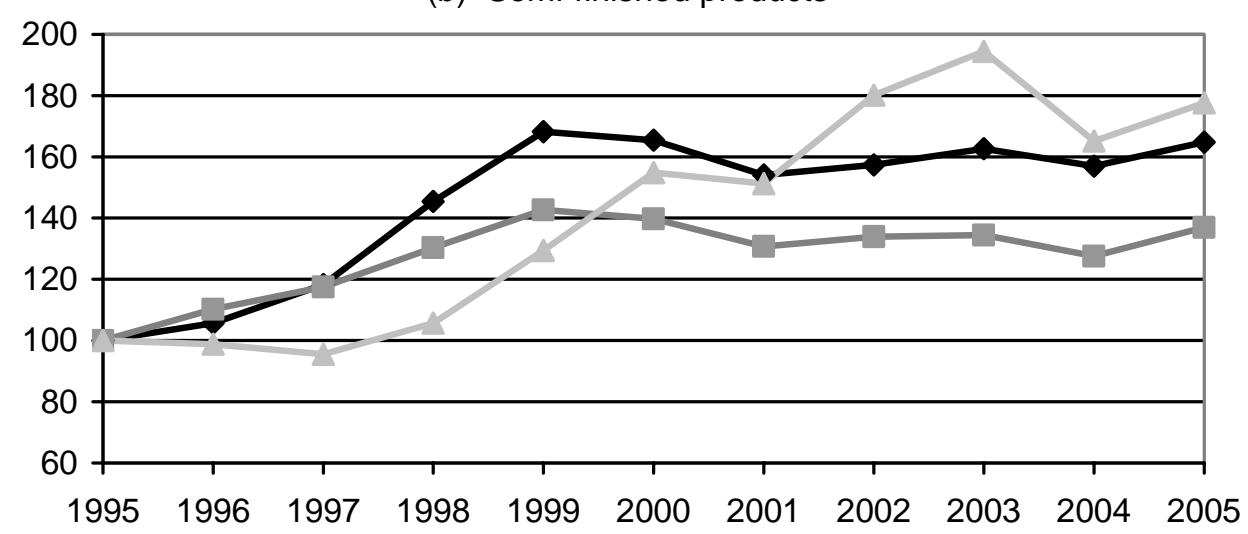

(c) Finished products

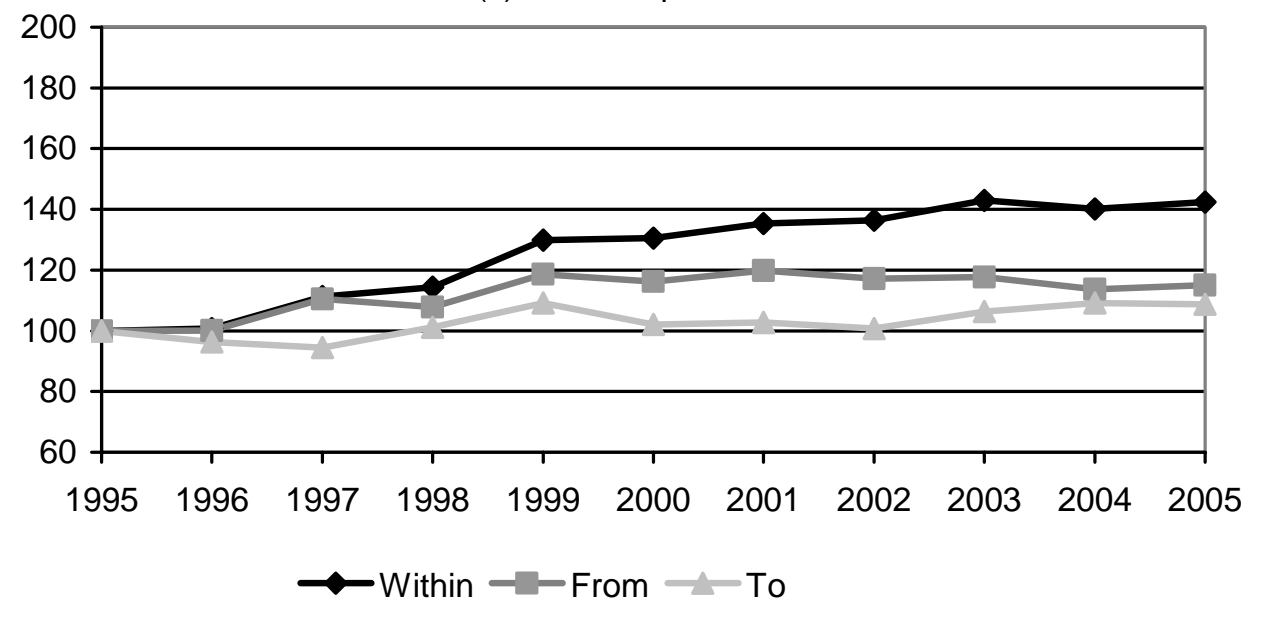


We employ the gravity equation to estimate euro effects for exports of raw materials, semi-finished and finished products. The specification of the gravity equation is altered by replacing GDP of the exporter as a measure of supply capacity by total exports of the respective products. The dependent variable is a component of the independent variable and can be correlated with it, which may give simultaneity bias (but this is also the case for the specification with GDP, since trade is a component of GDP).

Data on exports of product groups in current prices have been deflated by the exporter's producer price index. The appropriate procedure would have been to use a price index for each product group and stage of processing. Such price indices are however not available. ${ }^{6}$

Table 6 shows euro estimates for the three products groups relative to the OECD10 and EU-3 benchmarks respectively:

\footnotetext{
${ }^{6}$ Both value and physical quantity are reported at the HS six-digit level. The quantity data are however often missing and of poor quality. Our attempt to construct industry price indices produced implausible results and had to be abandoned.
} 
Table 6 Currency union effects on exports of raw materials, semi-finished and finished products

(a) 20 OECD countries

\begin{tabular}{|c|c|c|c|c|}
\hline & Total & $\begin{array}{l}\text { Raw } \\
\text { materials }\end{array}$ & $\begin{array}{l}\text { Inter- } \\
\text { mediates }\end{array}$ & $\begin{array}{l}\text { Finished } \\
\text { products }\end{array}$ \\
\hline EZ11p1 & $\begin{array}{l}0.165^{\star \star \star} \\
{[0.023]}\end{array}$ & $\begin{array}{l}0.061 \\
{[0.054]}\end{array}$ & $\begin{array}{l}0.212^{\star \star \star} \\
{[0.040]}\end{array}$ & $\begin{array}{l}0.190^{\star \star \star} \\
{[0.028]}\end{array}$ \\
\hline EZ11p2 & $\begin{array}{l}0.232^{\star \star \star} \\
{[0.024]}\end{array}$ & $\begin{array}{l}0.001 \\
{[0.054]}\end{array}$ & $\begin{array}{l}0.246^{\star \star \star} \\
{[0.039]}\end{array}$ & $\begin{array}{l}0.313^{\star \star \star} \\
{[0.027]}\end{array}$ \\
\hline EZ10p1 & $\begin{array}{l}0.074^{\star * *} \\
{[0.020]}\end{array}$ & $\begin{array}{l}0.083 \\
{[0.062]}\end{array}$ & $\begin{array}{l}0.099 * * * \\
{[0.033]}\end{array}$ & $\begin{array}{l}0.083^{\star \star \star} \\
{[0.024]}\end{array}$ \\
\hline EZ10p2 & $\begin{array}{l}0.113^{\star \star *} \\
{[0.022]}\end{array}$ & $\begin{array}{l}0.049 \\
{[0.061]}\end{array}$ & $\begin{array}{l}0.101 * \star \star \\
{[0.032]}\end{array}$ & $\begin{array}{l}0.155^{\star \star \star} \\
{[0.025]}\end{array}$ \\
\hline EZ01p1 & $\begin{array}{l}0.085^{\star \star \star} \\
{[0.025]}\end{array}$ & $\begin{array}{l}-0.036 \\
{[0.054]}\end{array}$ & $\begin{array}{l}0.129 * \star \star \\
{[0.050]}\end{array}$ & $\begin{array}{l}0.092^{\star \star \star} \\
{[0.030]}\end{array}$ \\
\hline EZ01p2 & $\begin{array}{l}0.120 * \star \star \\
{[0.026]}\end{array}$ & $\begin{array}{l}-0.084^{*} \\
{[0.049]}\end{array}$ & $\begin{array}{l}0.189 * \star \star \\
{[0.048]}\end{array}$ & $\begin{array}{l}0.151^{\star \star \star} \\
{[0.030]}\end{array}$ \\
\hline InRGDPx & $\begin{array}{l}0.590^{* \star *} \\
{[0.089]}\end{array}$ & $\begin{array}{l}0.075 \\
{[0.163]}\end{array}$ & $\begin{array}{l}1.101^{* * *} \\
{[0.180]}\end{array}$ & $\begin{array}{l}0.609 * \star \star \\
{[0.091]}\end{array}$ \\
\hline InRGDPm & $\begin{array}{l}1.185^{\star \star \star} \\
{[0.078]}\end{array}$ & $\begin{array}{l}0.920^{\star \star \star} \\
{[0.190]}\end{array}$ & $\begin{array}{l}0.993^{\star \star \star} \\
{[0.151]}\end{array}$ & $\begin{array}{l}1.008^{\star \star \star} \\
{[0.083]}\end{array}$ \\
\hline InREXRxm & $\begin{array}{l}-0.189 * \star \star \\
{[0.066]}\end{array}$ & $\begin{array}{l}-0.618^{\star \star \star} \\
{[0.141]}\end{array}$ & $\begin{array}{l}-0.298^{\star} \\
{[0.156]}\end{array}$ & $\begin{array}{l}-0.092 \\
{[0.072]}\end{array}$ \\
\hline InREXRcm & $\begin{array}{l}-0.297^{\star \star \star} \\
{[0.094]}\end{array}$ & $\begin{array}{l}0.359 \\
{[0.273]}\end{array}$ & $\begin{array}{l}0.274 \\
{[0.196]}\end{array}$ & $\begin{array}{l}-0.453^{\star \star} \\
{[0.102]}\end{array}$ \\
\hline InREXRxm-1 & $\begin{array}{l}-0.605^{\star \star \star} \\
{[0.067]}\end{array}$ & $\begin{array}{l}-0.659 \star \star \star \\
{[0.159]}\end{array}$ & $\begin{array}{l}-0.470^{\star \star \star} \\
{[0.151]}\end{array}$ & $\begin{array}{l}-0.601^{\star *} \\
{[0.073]}\end{array}$ \\
\hline InREXRcm-1 & $\begin{array}{l}0.392^{\star \star \star} \\
{[0.091]}\end{array}$ & $\begin{array}{l}0.481^{\star \star} \\
{[0.242]}\end{array}$ & $\begin{array}{l}0.096 \\
{[0.195]}\end{array}$ & $\begin{array}{l}0.394^{\star \star \star} \\
{[0.102]}\end{array}$ \\
\hline Observations & 4161 & 4161 & 4161 & 4161 \\
\hline Panels & 380 & 380 & 380 & 380 \\
\hline R-squared & 0.53 & 0.08 & 0.20 & 0.51 \\
\hline
\end{tabular}

Robust standard errors in brackets

* significant at $10 \%$; ** significant at 5\%; *** significant at $1 \%$

Country pair fixed effects, controls for deviations from GDP trend, Single Market participation 
Table 6 continued

(b) 13 EU countries

\begin{tabular}{|c|c|c|c|c|}
\hline & Total & $\begin{array}{l}\text { Raw } \\
\text { materials }\end{array}$ & $\begin{array}{l}\text { Inter- } \\
\text { mediates }\end{array}$ & $\begin{array}{l}\text { Finished } \\
\text { products }\end{array}$ \\
\hline EZ11p1 & $\begin{array}{l}0.114^{\star \star \star} \\
{[0.032]}\end{array}$ & $\begin{array}{l}-0.040 \\
{[0.067]}\end{array}$ & $\begin{array}{l}0.177^{\star \star \star} \\
{[0.048]}\end{array}$ & $\begin{array}{l}0.119^{\star \star \star} \\
{[0.036]}\end{array}$ \\
\hline EZ11p2 & $\begin{array}{l}0.187^{\star \star \star} \\
{[0.037]}\end{array}$ & $\begin{array}{l}-0.064 \\
{[0.050]}\end{array}$ & $\begin{array}{l}0.201^{\star \star \star} \\
{[0.041]}\end{array}$ & $\begin{array}{l}0.217^{\star \star \star} \\
{[0.044]}\end{array}$ \\
\hline EZ10p1 & $\begin{array}{l}0.032 \\
{[0.033]}\end{array}$ & $\begin{array}{l}0.091 \\
{[0.076]}\end{array}$ & $\begin{array}{l}0.094^{\star \star} \\
{[0.047]}\end{array}$ & $\begin{array}{l}0.024 \\
{[0.037]}\end{array}$ \\
\hline EZ10p2 & $\begin{array}{l}0.052 \\
{[0.039]}\end{array}$ & $\begin{array}{l}0.078 \\
{[0.058]}\end{array}$ & $\begin{array}{l}0.045 \\
{[0.043]}\end{array}$ & $\begin{array}{l}0.063 \\
{[0.046]}\end{array}$ \\
\hline EZ01p1 & $\begin{array}{l}0.053 \\
{[0.033]}\end{array}$ & $\begin{array}{l}-0.299 * \star \star \\
{[0.084]}\end{array}$ & $\begin{array}{l}0.106^{\star} \\
{[0.056]}\end{array}$ & $\begin{array}{l}0.061^{*} \\
{[0.037]}\end{array}$ \\
\hline EZ01p2 & $\begin{array}{l}0.086^{\star \star} \\
{[0.040]}\end{array}$ & $\begin{array}{l}-0.190^{\star \star \star} \\
{[0.054]}\end{array}$ & $\begin{array}{l}0.171^{\star \star \star} \\
{[0.049]}\end{array}$ & $\begin{array}{l}0.081^{*} \\
{[0.047]}\end{array}$ \\
\hline InRGDP_i & $\begin{array}{l}0.603^{\star * \star} \\
{[0.117]}\end{array}$ & $\begin{array}{l}0.229 \\
{[0.165]}\end{array}$ & $\begin{array}{l}1.458^{\star \star \star} \\
{[0.212]}\end{array}$ & $\begin{array}{l}0.501^{\star \star \star} \\
{[0.139]}\end{array}$ \\
\hline ذ_lnRGDP & $\begin{array}{l}1.198^{\star \star \star} \\
{[0.104]}\end{array}$ & $\begin{array}{l}1.018^{\star \star \star} \\
{[0.215]}\end{array}$ & $\begin{array}{l}1.104^{\star \star \star} \\
{[0.224]}\end{array}$ & $\begin{array}{l}1.176^{\star \star \star *} \\
{[0.101]}\end{array}$ \\
\hline InREXRij & $\begin{array}{l}-0.320^{\star \star \star} \\
{[0.113]}\end{array}$ & $\begin{array}{l}-0.816^{\star \star \star} \\
{[0.220]}\end{array}$ & $\begin{array}{l}-0.032 \\
{[0.175]}\end{array}$ & $\begin{array}{l}-0.439^{\star \star \star} \\
{[0.134]}\end{array}$ \\
\hline InREXRkj & $\begin{array}{l}-0.161 \\
{[0.153]}\end{array}$ & $\begin{array}{l}0.572^{\star} \\
{[0.331]}\end{array}$ & $\begin{array}{l}-0.162 \\
{[0.243]}\end{array}$ & $\begin{array}{l}-0.163 \\
{[0.177]}\end{array}$ \\
\hline InREXRij1 & $\begin{array}{l}-0.595^{\star \star \star} \\
{[0.108]}\end{array}$ & $\begin{array}{l}-0.441^{\star *} \\
{[0.219]}\end{array}$ & $\begin{array}{l}-0.576^{\star \star \star} \\
{[0.167]}\end{array}$ & $\begin{array}{l}-0.597^{\star * \star} \\
{[0.126]}\end{array}$ \\
\hline InREXRkj1 & $\begin{array}{l}0.464^{\star \star \star} \\
{[0.157]}\end{array}$ & $\begin{array}{l}0.734^{\star \star} \\
{[0.337]}\end{array}$ & $\begin{array}{l}0.631^{\star \star \star} \\
{[0.230]}\end{array}$ & $\begin{array}{l}0.453^{\star \star} \\
{[0.184]}\end{array}$ \\
\hline Observations & 1704 & 1704 & 1704 & 1704 \\
\hline Panels & 156 & 156 & 156 & 156 \\
\hline R-squared & 0.65 & 0.18 & 0.43 & 0.62 \\
\hline
\end{tabular}

Robust standard errors in brackets

* significant at $10 \%$; ** significant at $5 \%$; *** significant at $1 \%$

Country pair fixed effects, controls for deviations from GDP trend, Single Market participation 
The currency union estimates for semi-finished and finished products in the OECD-20 country sample have expected positive signs, are of similar magnitude and highly significant, whereas the estimates for raw materials are insignificant (with one exception) and the equation for raw materials has low explanatory power. The estimates in the case of the EU-13 sample show a similar pattern, although fewer estimates are significant. It is clear that the inclusion of raw materials reduces the overall estimates and that the large and positive currency union effects for aggregate exports should be attributed to effects on trade in semi-finished and finished products.

\section{Currency union effects at the industry level}

We do not think that the estimated currency union effects for raw materials exports can be taken at face value. This becomes more evident when looking at estimates of currency union effects at the industry level.

Table A6 reports currency union estimates for individual industries at the ISIC two-digit level. ${ }^{7}$ The industry trade data was compiled from HS six-digit level trade data using concordance tables available in the WITS portal.

Practically no effects are found in agriculture and related activities (01-05), mining and quarrying (10-14), and low-tech or raw materials based industries, such as food products (15-16), textiles and footwear (17-19), pulp and paper (21) or petroleum products (23). Significant, positive and large currency union effects are found exclusively (with one or two exceptions) in chemical, metal product and engineering industries (2436). Among the industries that stand out in terms of significant and large positive effects are pharmaceuticals (2423), rubber and plastic products (25), metals and fabricated metal products (27-28), machinery and equipment (29-33) and transport equipment (34-35). These are categories where the raw material component of the price generally is low because of the amount of processing involved, and where the aggregate producer price index should correspond approximately to the relevant product group price index.

\footnotetext{
7 The estimates reported in Table A6 were produced with a modified gravity equation. The respective industry's total exports was used as a measure of supply capacity, instead of deviation from trend GDP, and the trade shares used to compute competitors' real exchange rates are for competitors' exports in the same industry.
} 
The conclusion that can be drawn from the industry estimates is that the currency union effects on aggregate trade can be attributed to trade in highly processed product groups that have relatively large shares of output and trade. The effects for raw materials and low-tech products are unclear. The high frequency of implausible point estimates for agriculture and other raw materials based industries where prices are known to vary, such as for petroleum products, indicate that these estimates are much influenced by remaining price effects in the data after deflating with producer price indices.

\section{Conclusion and summary}

We conclude that our estimates do show that the formation of the European currency union in 1999 has affected international trade; the fact that annual estimates become significant in 1999 or 2000 and that the estimates for 1999-2005 are significantly higher than the estimates for 1995-1998 (particularly in the sample of 20 OECD countries) provide strong support for the presence of such effects.

We estimate that the currency union has increased the level of exports in 20022005 relative to 1995-1998 between currency union members by 26 per cent relative to ten outside OECD countries and by 21 per cent relative to three outside EU countries. Exports from member to outside countries has been increased by 12 per cent compared to exports between the ten outside OECD countries, and exports from outside to member countries has been increased by 13 per cent compared to the ten outside OECD countries and by 9 per cent compared to the three outside EU countries.

The currency union effects on trade are surprisingly large considering the small costs of currency exchange and hedging and considering the consensus of the extensive empirical literature on nominal exchange rate uncertainty that such uncertainty has very small or no effects on trade. We argue that these findings are irrelevant; the switch from flexible nominal exchange rates to fixed nominal exchange rates provided by a common currency is likely to reduce uncertainty to a much larger extent than a reduction in the volatility of nominal exchange rates under a regime of flexible exchange rates, and should therefore have much larger effects of trade. Furthermore, the literature has dealt with high frequency exchange rate changes, not longer term changes, which are much harder to hedge against. 
That the currency union has served to increase trade between member and outside countries is contrary to the prediction of customs union theory. The elimination of costs of currency exchange and hedging inside the currency union should have induced importers to switch from outside to more competitive inside suppliers. The increase in exports from outside countries to member countries could be explained by the existence of fixed costs of exporting, which have led outside exporters to set up distribution, sales and marketing facilities in one of the currency union countries. When trade costs were lowered inside the currency union, such outsiders gained almost as much as exporters inside the currency union. Also, the lower trade costs could have been sufficient to cover fixed costs of exporting on the margin and could thereby have induced new exports from outside exporters. The increase in exports from member to outside countries could be explained by lower costs of purchasing inputs from other countries inside the customs union, which have made exporters in member countries more competitive.

We find significant increases in the number of exported statistical product categories at the HS six-digit level. We take this as an indication of currency union effects on the extensive margin of trade. The number of exported product categories in 2002-2005 relative to 1995-1998 is increased by about 6 per cent between currency union member countries and by about 4 per cent between member and outside countries compared the ten outside OECD countries. No significant external margin effects were found in the EU country sample.

In order to assess the relative importance of intensive and external margin effects on trade, we make use of the six-digit level HS product categories and define the intensive margin as consisting of product categories for which positive exports are registered each and every year during the sample period in the 1.9 million panels in our dataset. The difference between total exports and these "core" exports is defined as the extensive margin of trade. The extensive margin consists of all product categories for which zero exports were registered in at least one year during the sample period. Some of these product categories ceased to be exported, some were exported intermittently and some started to be exported after 1995 and were exported every subsequent year during the sample period. The latter correspond most closely to the theoretical concept of the external margin. The products belonging to our definition of the external margin make up 
11-18 per cent of the total in the pre-currency years, 1995-1998, depending on the category of trade relation (within, to, from or outside eurozone). We find that both intensive and extensive margin currency union effects are highly significant and that the external margin effects are significantly larger than the intensive margin effects. About 25 per cent of the total effect for exports within the eurozone can be attributed to extensive margin effects. The corresponding shares for exports from and to the eurozone are 20 and 15 per cent respectively.

When we estimate currency union effects at different stages of processing and for different industries, we find significant, positive and large effects for semi-finished and finished products and for industries with highly processed products for which raw material prices play a relatively small role for the price of the finished product. Estimates for exports of agricultural products and products where raw material prices play a relatively large role are largely insignificant, erratic or implausible. A case in point is oil and oil products. It is likely that the estimates for oil and other raw material exports reflect price changes that remain after deflating with producer price indices. 


\section{References}

Anderson, James (1979), “The theoretical foundations for the gravity equation”, American Economic Review 69, 106-116.

Baldwin, Richard and Daria Taglioni (2004), "Positive OCA criteria: Microfoundations for the Rose effect”, unpublished manuscript, http://hei.unige.ch/\%7Ebaldwin/PapersBooks/OCA_BaldwinTaglioni17Mar04.pdf

Baldwin, Richard (2006), “The euro’s trade effects”, unpublished manuscript, http://hei.unige.ch/ baldwin/AcademicPapers/AcademicPaperFiles/Euros_Trade_Effect_ baldwin_24Nov05.pdf

Baldwin, Richard and Virginia Di Nino (2006), “Euros and zeros: The common currency effect on trade in new goods," http://hei.unige.ch/ baldwin/PapersBooks/BaldwinDiNino_31Oct06_Submitted.pdf

Berger, Helge and Volker Nitsch (2205), “Zooming out: The trade effect of the euro in historical perspective”, CESifo Working Paper No. 1435.

Calmfors, Lars et al (1997), EMU - A Swedish perspective (Boston, Dordrecht, London: Kluwer Academic Publishers).

Deardorff, Alan (1998), “Determinants of bilateral trade: Does gravity work in a neoclassical world?”, in Jeffrey Frankel (ed.), The regionalization of the world economy (Chicago: The University of Chicago Press).

Flam, Harry and Håkan Nordström (2003), “Trade volume effects of the euro: Aggregate and sector estimates”, unpublished manuscript, http://www.iies.su.se/publications/seminarpapers/746.pdf 
Helpman, Elhanan and Paul Krugman (1985), Market structure and foreign trade (Cambridge: The MIT Press).

IMF (2004), "Exchange rate volatility - some new evidence", www.imf.org/external/np/res/exrate/2004/eng/051904.pdf

McKenzie, Michael D. (1999), “The impact of exchange rate volatility on international trade flows”, Journal of economic surveys 13, 71-106.

Melitz, Marc (2003), “The impact of trade on intraindustry reallocations and aggregate industry productivity”, Econometrica 71, 1695-1725.

Roberts, Mark J. and James R. Tybout (1997), “The decision to export in Colombia: An empirical model of entry with sunk costs”, American Economic Review 87, 545-564.

Rose, Andrew K. (2000), “One money, one market: Estimating the effect of common currencies on trade”, Economic Policy 30, 9-45.

Rose, Andrew K. (2001), “Currency unions and trade: The effect is large”, Economic Policy 33, 449-461.

Yi, Kei-Mu (2003), “Can vertical specialization explain the growth of world trade?”, Journal of Political Economy 111, 52-102. 
Table A1 Annual currency union effects

\begin{tabular}{|c|c|c|c|c|c|c|c|c|}
\hline & \multicolumn{3}{|c|}{ Within eurozone } & \multicolumn{3}{|c|}{ From eurozone } & \multicolumn{2}{|c|}{ To eurozone } \\
\hline & OECD-20 & EU-13 & & OECD-20 & EU-13 & & OECD-20 & EU-13 \\
\hline EZ11t96 & $\begin{array}{l}0.026 \\
{[0.048]}\end{array}$ & $\begin{array}{l}-0.022 \\
{[0.083]}\end{array}$ & EZ10t96 & $\begin{array}{l}0.014 \\
{[0.044]}\end{array}$ & $\begin{array}{l}-0.020 \\
{[0.088]}\end{array}$ & EZ01t96 & $\begin{array}{l}-0.022 \\
{[0.051]}\end{array}$ & $\begin{array}{l}-0.044 \\
{[0.089]}\end{array}$ \\
\hline EZ11t97 & $\begin{array}{l}0.083 \\
{[0.050]}\end{array}$ & $\begin{array}{l}-0.011 \\
{[0.077]}\end{array}$ & EZ10t97 & $\begin{array}{l}0.050 \\
{[0.049]}\end{array}$ & $\begin{array}{l}0.004 \\
{[0.081]}\end{array}$ & EZ01t97 & $\begin{array}{l}-0.004 \\
{[0.049]}\end{array}$ & $\begin{array}{l}-0.070 \\
{[0.080]}\end{array}$ \\
\hline EZ11t98 & $\begin{array}{l}0.073 \\
{[0.046]}\end{array}$ & $\begin{array}{l}0.015 \\
{[0.071]}\end{array}$ & EZ10t98 & $\begin{array}{l}0.036 \\
{[0.043]}\end{array}$ & $\begin{array}{l}-0.033 \\
{[0.075]}\end{array}$ & EZ01t98 & $\begin{array}{l}0.018 \\
{[0.049]}\end{array}$ & $\begin{array}{l}-0.003 \\
{[0.076]}\end{array}$ \\
\hline EZ11t99 & $\begin{array}{l}0.182^{\star \star \star} \\
{[0.043]}\end{array}$ & $\begin{array}{l}0.132^{\star} \\
{[0.068]}\end{array}$ & EZ10t99 & $\begin{array}{l}0.095^{\star \star} \\
{[0.040]}\end{array}$ & $\begin{array}{l}0.051 \\
{[0.071]}\end{array}$ & EZ01t99 & $\begin{array}{l}0.059 \\
{[0.043]}\end{array}$ & $\begin{array}{l}0.059 \\
{[0.071]}\end{array}$ \\
\hline EZ11t00 & $\begin{array}{l}0.230^{* \star \star} \\
{[0.045]}\end{array}$ & $\begin{array}{l}0.124 \\
{[0.075]}\end{array}$ & EZ10t00 & $\begin{array}{l}0.105^{\star \star \star} \\
{[0.040]}\end{array}$ & $\begin{array}{l}0.016 \\
{[0.078]}\end{array}$ & EZ01t00 & $\begin{array}{l}0.089^{\star} \\
{[0.048]}\end{array}$ & $\begin{array}{l}0.020 \\
{[0.078]}\end{array}$ \\
\hline EZ11t01 & $\begin{array}{l}0.225^{\star \star *} \\
{[0.043]}\end{array}$ & $\begin{array}{l}0.077 \\
{[0.068]}\end{array}$ & EZ10t01 & $\begin{array}{l}0.099 * * \\
{[0.040]}\end{array}$ & $\begin{array}{l}-0.009 \\
{[0.072]}\end{array}$ & EZ01t01 & $\begin{array}{l}0.106^{\star *} \\
{[0.045]}\end{array}$ & $\begin{array}{l}-0.001 \\
{[0.071]}\end{array}$ \\
\hline EZ11t02 & $\begin{array}{l}0.240^{\star \star *} \\
{[0.047]}\end{array}$ & $\begin{array}{l}0.114 \\
{[0.087]}\end{array}$ & EZ10t02 & $\begin{array}{l}0.109^{\star *} \\
{[0.043]}\end{array}$ & $\begin{array}{l}0.010 \\
{[0.091]}\end{array}$ & EZ01t02 & $\begin{array}{l}0.104^{\star *} \\
{[0.049]}\end{array}$ & $\begin{array}{l}0.009 \\
{[0.091]}\end{array}$ \\
\hline EZ11t03 & $\begin{array}{l}0.265^{\star \star \star} \\
{[0.044]}\end{array}$ & $\begin{array}{l}0.206^{\star \star \star} \\
{[0.080]}\end{array}$ & EZ10t03 & $\begin{array}{l}0.106^{\star \star \star} \\
{[0.041]}\end{array}$ & $\begin{array}{l}0.049 \\
{[0.084]}\end{array}$ & EZ01t03 & $\begin{array}{l}0.113^{\star *} \\
{[0.044]}\end{array}$ & $\begin{array}{l}0.080 \\
{[0.083]}\end{array}$ \\
\hline EZ11t04 & $\begin{array}{l}0.312^{\star \star *} \\
{[0.050]}\end{array}$ & $\begin{array}{l}0.214^{\star \star \star \star} \\
{[0.082]}\end{array}$ & EZ10t04 & $\begin{array}{l}0.152^{\star \star \star} \\
{[0.049]}\end{array}$ & $\begin{array}{l}0.047 \\
{[0.088]}\end{array}$ & EZ01t04 & $\begin{array}{l}0.147^{\star \star \star} \\
{[0.051]}\end{array}$ & $\begin{array}{l}0.079 \\
{[0.089]}\end{array}$ \\
\hline EZ11t05 & $\begin{array}{l}0.297^{\star \star \star} \\
{[0.051]}\end{array}$ & $\begin{array}{l}0.202^{\star \star \star} \\
{[0.075]}\end{array}$ & EZ10t05 & $\begin{array}{l}0.187^{\star \star \star} \\
{[0.047]}\end{array}$ & $\begin{array}{l}0.049 \\
{[0.081]}\end{array}$ & EZ01t05 & $\begin{array}{l}0.112^{\star \star} \\
{[0.056]}\end{array}$ & $\begin{array}{l}0.073 \\
{[0.088]}\end{array}$ \\
\hline Observations & 4161 & 1704 & & & & & & \\
\hline Panels & 380 & 156 & & & & & & \\
\hline R-squared & 0.53 & 0.65 & & & & & & \\
\hline
\end{tabular}

OLS, robust standard errors in brackets

* significant at 10\%; ** significant at $5 \%$; *** significant at $1 \%$

Country pair fixed effects, controls for GDP, deviations from trend GDP, real exchange rates, Single Market participation, common year effects. 
Table A2 Tests of differences between annual coefficients

(a) 20 OECD countries

Within eurozone

\begin{tabular}{|c|c|c|c|c|c|c|c|c|c|c|}
\hline & 1996 & 1997 & 1998 & 1999 & 2000 & 2001 & 2002 & 2003 & 2004 & 2005 \\
\hline 1996 & & & & & & & & & & \\
\hline 1997 & 1.32 & & & & & & & & & \\
\hline 1998 & 1.21 & 0.02 & & & & & & & & \\
\hline 1999 & $17.02^{\star \star \star}$ & $7.12^{\star \star \star}$ & $10.48^{\star \star \star}$ & & & & & & & \\
\hline 2000 & $22.37^{\star \star \star}$ & $11.24^{\star \star \star}$ & $15.81^{\star \star \star}$ & 0.99 & & & & & & \\
\hline 2001 & $23.92^{\star \star \star}$ & $11.37^{\star \star \star}$ & $16.69 * \star \star$ & 0.98 & 0.00 & & & & & \\
\hline 2002 & $15.17^{\star \star \star}$ & $6.31^{* \star}$ & $8.83^{\star \star \star}$ & 0.01 & 1.11 & 1.15 & & & & \\
\hline 2003 & $32.60 * \star \star$ & $17.35^{\star \star \star}$ & $23.99 * \star \star$ & $4.13^{\star \star}$ & 0.99 & 1.27 & $4.46^{\star \star}$ & & & \\
\hline 2004 & $36.54^{\star \star *}$ & $21.67^{\star \star \star}$ & $26.84^{\star \star *}$ & $7.52^{\star \star \star}$ & $3.35^{\star}$ & $3.82^{\star}$ & 7.70 ** & 1.02 & & \\
\hline 2005 & $30.29 * \star \star$ & $17.46^{\star \star \star}$ & $21.32^{\star \star \star}$ & $5.00 * \star$ & 1.96 & 2.23 & $5.21^{\star *}$ & 0.38 & 0.10 & \\
\hline
\end{tabular}

From eurozone

$\begin{array}{llllllllll}1996 & 1997 & 1998 & 1999 & 2000 & 2001 & 2002 & 2003 & 2004 & 2005\end{array}$

1996

1997

1998

1999

2000

2001

2002

2003

2004

2005

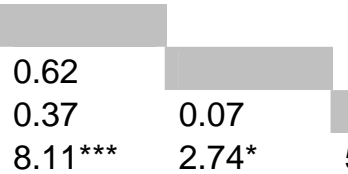

$8.11^{\star \star \star} \quad 2.74$

$6.27^{* *} \quad 1.89$

$5.67 \quad 1.57$

$4.11^{* *}$

0.12

1.57
0.37

1.14

0.22

1.80

0.02

$6.44^{\star \star} \quad 1.97$

$4.15^{\star \star}$

0.05

$0.92 \quad 0.69$

$9.34^{* *}$

$4.34^{\star *}$

$6.98^{\star \star \star}$

0.82

$0.01 \quad 0.06$

$1.31 \quad 1.55$

1.09

$15.25^{\star \star \star} 7.93^{\star \star \star}$

12.08 ***

$3.11^{\star} 3.96^{\star \star} 4.36^{\star *}$

$3.47^{*} \quad 1.09$

$7.28^{* * *} 3.52^{*}$

0.48

To eurozone

$\begin{array}{llllllllll}1996 & 1997 & 1998 & 1999 & 2000 & 2001 & 2002 & 2003 & 2004 & 2005\end{array}$

1996

1997

1998

1999

2000

2001

2002

2003

2004

2005

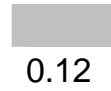

0.61

3.88 *

0.20

$4.97 * \star$

$7.16^{\star \star \star}$

3.86 **

$5.75^{\star \star}$

1.41

$3.52^{\star}$

2.45

3.98 **

0.28

$8.47^{* *}$

$6.90^{\star * *}$

1.24

1.01

0.00

0.16

$10.36^{\star * *}$

1.55

0.22

0.35

$6.67^{\star \star \star} \quad 3.15^{\star}$

1.39

$5.35^{\star \star}$

$4.25^{\star \star}$

$2.89 *$

0.77

0.18

0.84

0.04

0.76

0.01

1.29

$2.77^{*}$

0.69

0.50

0.00

0.37 
(b) 13 EU countries

Within eurozone

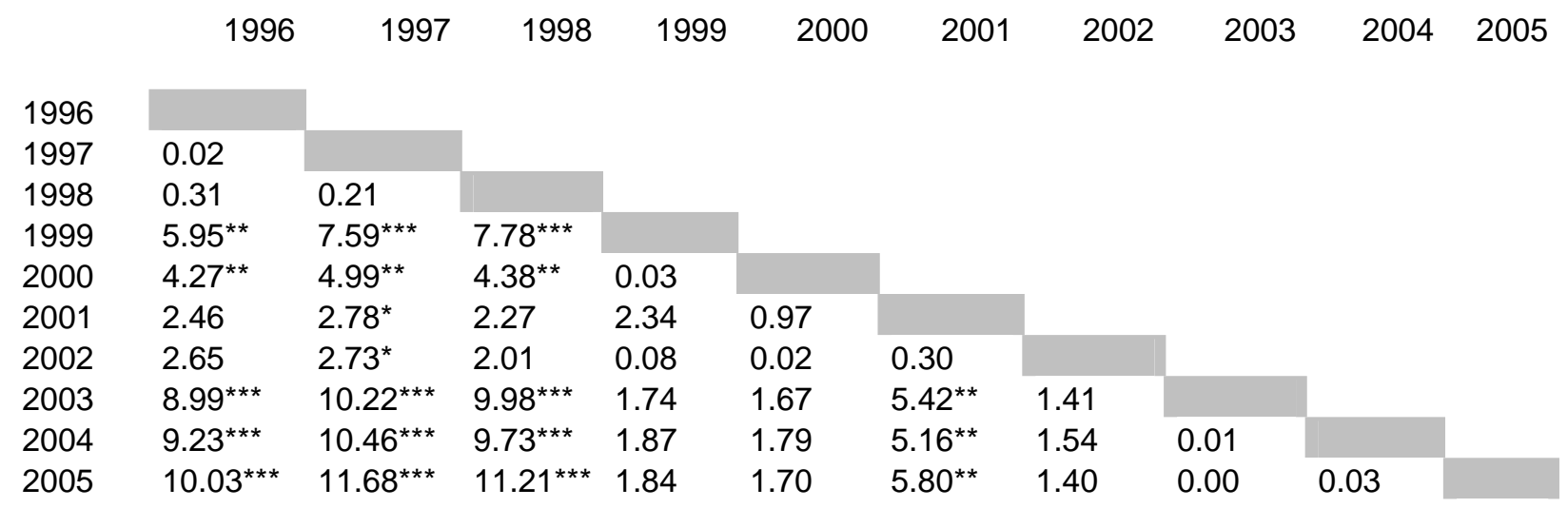

From eurozone

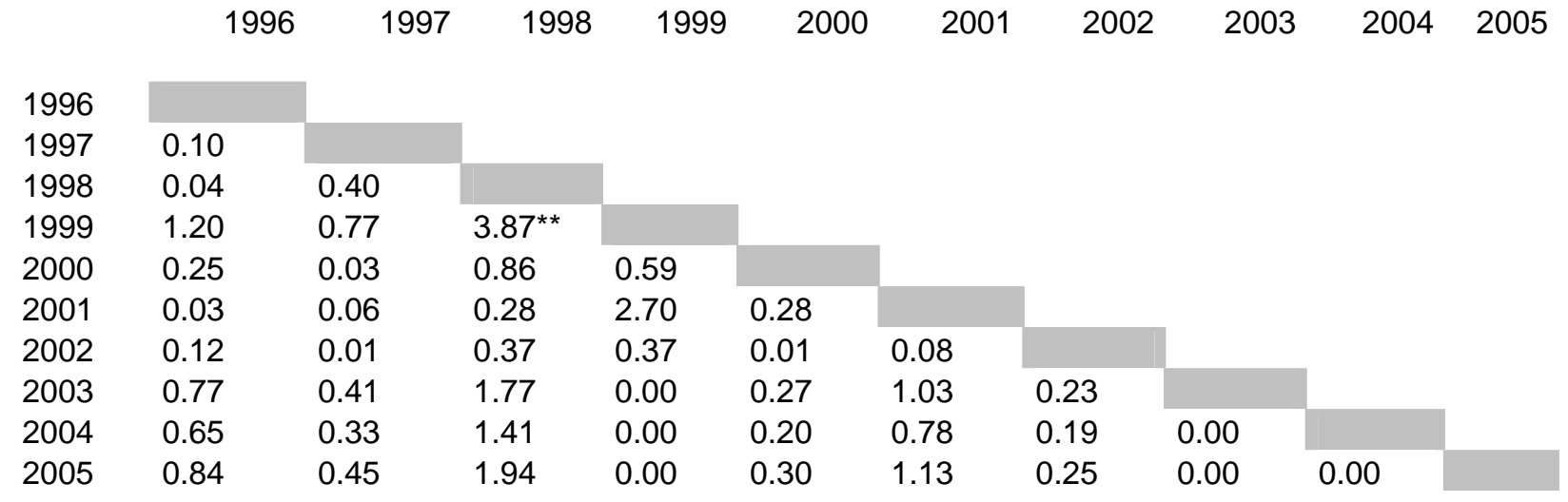

To eurozone

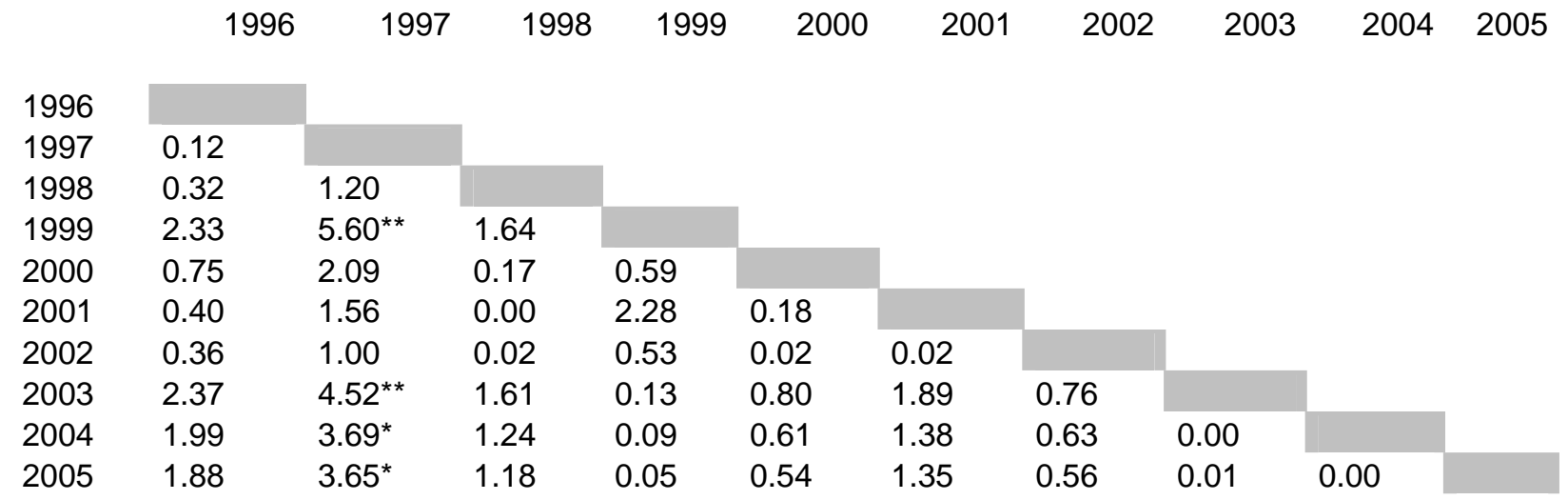

F-values of Wald test

* significant at $10 \%$, ** significant at $5 \%$, significant at $1 \%$ 
Table A3 Robustness check: Specification

(a) 20 OECD countries

\begin{tabular}{|c|c|c|c|c|c|}
\hline EZ11p1 & $\begin{array}{l}0.165^{\star \star \star} \\
{[0.023]}\end{array}$ & $\begin{array}{l}0.179 * \star \star \\
{[0.023]}\end{array}$ & $\begin{array}{l}0.164^{\star \star \star} \\
{[0.023]}\end{array}$ & $\begin{array}{l}0.191^{\star \star \star} \\
{[0.023]}\end{array}$ & $\begin{array}{l}0.237^{\star \star \star} \\
{[0.024]}\end{array}$ \\
\hline EZ11p2 & $\begin{array}{l}0.232^{\star \star \star} \\
{[0.024]}\end{array}$ & $\begin{array}{l}0.250 * \star \star \\
{[0.023]}\end{array}$ & $\begin{array}{l}0.234^{\star \star \star} \\
{[0.024]}\end{array}$ & $\begin{array}{l}0.238^{\star \star \star} \\
{[0.025]}\end{array}$ & $\begin{array}{l}0.287^{\star \star \star} \\
{[0.026]}\end{array}$ \\
\hline EZ10p1 & $\begin{array}{l}0.074^{\star \star \star} \\
{[0.020]}\end{array}$ & $\begin{array}{l}0.094^{\star \star \star} \\
{[0.021]}\end{array}$ & $\begin{array}{l}0.074^{\star \star \star} \\
{[0.021]}\end{array}$ & $\begin{array}{l}0.136^{\star \star \star} \\
{[0.022]}\end{array}$ & $\begin{array}{l}0.148^{\star \star \star} \\
{[0.023]}\end{array}$ \\
\hline EZ10p2 & $\begin{array}{l}0.113^{\star * \star} \\
{[0.022]}\end{array}$ & $\begin{array}{l}0.139 * * \star \\
{[0.022]}\end{array}$ & $\begin{array}{l}0.112^{\star \star \star \star} \\
{[0.022]}\end{array}$ & $\begin{array}{l}0.162^{\star \star \star} \\
{[0.023]}\end{array}$ & $\begin{array}{l}0.175^{\star \star \star} \\
{[0.024]}\end{array}$ \\
\hline EZ01p1 & $\begin{array}{l}0.085^{\star \star *} \\
{[0.025]}\end{array}$ & $\begin{array}{l}0.078^{\star * *} \\
{[0.025]}\end{array}$ & $\begin{array}{l}0.084^{\star * *} \\
{[0.025]}\end{array}$ & $\begin{array}{l}0.048^{\star} \\
{[0.025]}\end{array}$ & $\begin{array}{l}0.082^{\star \star \star} \\
{[0.026]}\end{array}$ \\
\hline EZ01p2 & $\begin{array}{l}0.120^{\star \star \star} \\
{[0.026]}\end{array}$ & $\begin{array}{l}0.111^{\star \star \star} \\
{[0.026]}\end{array}$ & $\begin{array}{l}0.124^{\star \star \star} \\
{[0.026]}\end{array}$ & $\begin{array}{l}0.077^{\star \star \star} \\
{[0.026]}\end{array}$ & $\begin{array}{l}0.113^{\star \star \star} \\
{[0.027]}\end{array}$ \\
\hline InRGDPx & $\begin{array}{l}0.590^{\star * \star} \\
{[0.089]}\end{array}$ & $\begin{array}{l}0.546^{\star \star \star} \\
{[0.089]}\end{array}$ & $\begin{array}{l}0.592^{\star \star \star} \\
{[0.089]}\end{array}$ & $\begin{array}{l}0.439 * \star \star \\
{[0.092]}\end{array}$ & \\
\hline InRGDPm & $\begin{array}{l}1.185^{\star \star \star} \\
{[0.078]}\end{array}$ & $\begin{array}{l}1.198^{\star \star \star} \\
{[0.078]}\end{array}$ & $\begin{array}{l}1.179 \star \star \star \\
{[0.079]}\end{array}$ & $\begin{array}{l}1.211^{\star \star \star} \\
{[0.082]}\end{array}$ & \\
\hline GAPx & $\begin{array}{l}0.004 \\
{[0.003]}\end{array}$ & $\begin{array}{l}0.007^{\star *} \\
{[0.003]}\end{array}$ & $\begin{array}{l}0.004 \\
{[0.003]}\end{array}$ & & \\
\hline GAPm & $\begin{array}{l}0.015^{\star \star \star} \\
{[0.003]}\end{array}$ & $\begin{array}{l}0.014^{\star * *} \\
{[0.003]}\end{array}$ & $\begin{array}{l}0.014^{\star \star \star} \\
{[0.003]}\end{array}$ & & \\
\hline InREXRxm & $\begin{array}{l}-0.189 * \star * \\
{[0.066]}\end{array}$ & $\begin{array}{l}-0.597^{\star * *} \\
{[0.049]}\end{array}$ & & & \\
\hline InREXRcm & $\begin{array}{l}-0.297^{\star \star \star} \\
{[0.094]}\end{array}$ & $\begin{array}{l}-0.034 \\
{[0.070]}\end{array}$ & & & \\
\hline InREXRxm-1 & $\begin{array}{l}-0.605^{\star \star \star} \\
{[0.067]}\end{array}$ & & $\begin{array}{l}-0.749 * \star \star \\
{[0.050]}\end{array}$ & & \\
\hline InREXRcm-1 & $\begin{array}{l}0.392^{\star * \star} \\
{[0.091]}\end{array}$ & & $\begin{array}{l}0.168^{\star *} \\
{[0.069]}\end{array}$ & & \\
\hline Observations & 4161 & 4161 & 4161 & 4161 & 4161 \\
\hline Panels & 380 & 380 & 380 & 380 & 380 \\
\hline R-squared & 0.53 & 0.51 & 0.52 & 0.47 & 0.41 \\
\hline
\end{tabular}

OLS, robust standard errors in brackets

* significant at $10 \%$; ** significant at $5 \%$; ${ }^{* \star *}$ significant at $1 \%$

Country pair fixed effects, controls for Single Market participation and common year effects 
(b) $13 \mathrm{EU}$ countries

\begin{tabular}{|c|c|c|c|c|c|c|}
\hline EZ11p1 & $\begin{array}{l}0.114^{\star \star \star} \\
{[0.032]}\end{array}$ & $\begin{array}{l}0.136^{\star \star \star} \\
{[0.032]}\end{array}$ & $\begin{array}{l}0.116^{\star \star \star} \\
{[0.033]}\end{array}$ & $\begin{array}{l}0.144^{\star \star \star} \\
{[0.035]}\end{array}$ & $\begin{array}{l}0.158^{\star \star \star} \\
{[0.034]}\end{array}$ & $\begin{array}{l}0.200^{\star \star \star} \\
{[0.033]}\end{array}$ \\
\hline EZ11p2 & $\begin{array}{l}0.187^{\star \star \star} \\
{[0.037]}\end{array}$ & $\begin{array}{l}0.209 \star \star \star \\
{[0.037]}\end{array}$ & $\begin{array}{l}0.191^{\star \star \star} \\
{[0.038]}\end{array}$ & $\begin{array}{l}0.212^{\star \star \star} \\
{[0.041]}\end{array}$ & $\begin{array}{l}0.158^{\star \star \star} \\
{[0.038]}\end{array}$ & $\begin{array}{l}0.201^{\star \star \star} \\
{[0.038]}\end{array}$ \\
\hline EZ10p1 & $\begin{array}{l}0.032 \\
{[0.033]}\end{array}$ & $\begin{array}{l}0.059^{\star} \\
{[0.033]}\end{array}$ & $\begin{array}{l}0.027 \\
{[0.034]}\end{array}$ & $\begin{array}{l}0.092^{\star *} \\
{[0.037]}\end{array}$ & $\begin{array}{l}0.101^{\star \star \star} \\
{[0.036]}\end{array}$ & $\begin{array}{l}0.115^{\star \star \star} \\
{[0.036]}\end{array}$ \\
\hline EZ10p2 & $\begin{array}{l}0.052 \\
{[0.039]}\end{array}$ & $\begin{array}{l}0.080^{\star *} \\
{[0.039]}\end{array}$ & $\begin{array}{l}0.044 \\
{[0.040]}\end{array}$ & $\begin{array}{l}0.092^{\star *} \\
{[0.043]}\end{array}$ & $\begin{array}{l}0.062 \\
{[0.042]}\end{array}$ & $\begin{array}{l}0.078^{\star} \\
{[0.040]}\end{array}$ \\
\hline EZ01p1 & $\begin{array}{l}0.053 \\
{[0.033]}\end{array}$ & $\begin{array}{l}0.047 \\
{[0.034]}\end{array}$ & $\begin{array}{l}0.060^{\star} \\
{[0.035]}\end{array}$ & $\begin{array}{l}0.022 \\
{[0.038]}\end{array}$ & $\begin{array}{l}0.028 \\
{[0.036]}\end{array}$ & $\begin{array}{l}0.055 \\
{[0.037]}\end{array}$ \\
\hline EZ01p2 & $\begin{array}{l}0.086^{\star *} \\
{[0.040]}\end{array}$ & $\begin{array}{l}0.081^{\star *} \\
{[0.040]}\end{array}$ & $\begin{array}{l}0.099 \star \star \\
{[0.042]}\end{array}$ & $\begin{array}{l}0.072 \\
{[0.044]}\end{array}$ & $\begin{array}{l}0.048 \\
{[0.043]}\end{array}$ & $\begin{array}{l}0.076^{\star} \\
{[0.043]}\end{array}$ \\
\hline InRGDPx & $\begin{array}{l}0.603^{\star \star *} \\
{[0.117]}\end{array}$ & $\begin{array}{l}0.581^{\star \star \star} \\
{[0.118]}\end{array}$ & $\begin{array}{l}0.636^{\star \star \star} \\
{[0.118]}\end{array}$ & $\begin{array}{l}0.715^{\star \star \star} \\
{[0.121]}\end{array}$ & $\begin{array}{l}0.520 \star * \star \\
{[0.121]}\end{array}$ & \\
\hline InRGDPm & $\begin{array}{l}1.198^{\star \star \star} \\
{[0.104]}\end{array}$ & $\begin{array}{l}1.202^{\star \star \star} \\
{[0.106]}\end{array}$ & $\begin{array}{l}1.147^{\star \star \star} \\
{[0.104]}\end{array}$ & $\begin{array}{l}1.093^{\star \star \star} \\
{[0.111]}\end{array}$ & $\begin{array}{l}0.953^{\star \star \star} \\
{[0.111]}\end{array}$ & \\
\hline GAPx & $\begin{array}{l}0.023^{\star \star \star} \\
{[0.006]}\end{array}$ & $\begin{array}{l}0.026^{\star \star \star} \\
{[0.006]}\end{array}$ & $\begin{array}{l}0.023^{\star \star *} \\
{[0.006]}\end{array}$ & $\begin{array}{l}0.033^{\star \star \star} \\
{[0.006]}\end{array}$ & & \\
\hline GAPm & $\begin{array}{l}0.032^{\star \star \star} \\
{[0.006]}\end{array}$ & $\begin{array}{l}0.032^{\star \star \star} \\
{[0.006]}\end{array}$ & $\begin{array}{l}0.032^{\star \star \star} \\
{[0.006]}\end{array}$ & $\begin{array}{l}0.025^{\star \star *} \\
{[0.006]}\end{array}$ & & \\
\hline InREXRxm & $\begin{array}{l}-0.320^{\star \star \star} \\
{[0.113]}\end{array}$ & $\begin{array}{l}-0.743^{\star \star \star} \\
{[0.086]}\end{array}$ & & & & \\
\hline InREXRcm & $\begin{array}{l}-0.161 \\
{[0.153]}\end{array}$ & $\begin{array}{l}0.168 \\
{[0.111]}\end{array}$ & & & & \\
\hline InREXRxm-1 & $\begin{array}{l}-0.595^{\star \star \star} \\
{[0.108]}\end{array}$ & & $\begin{array}{l}-0.843^{\star \star \star} \\
{[0.085]}\end{array}$ & & & \\
\hline InREXRcm-1 & $\begin{array}{l}0.464^{\star \star \star} \\
{[0.157]}\end{array}$ & & $\begin{array}{l}0.341^{\star \star \star} \\
{[0.115]}\end{array}$ & & & \\
\hline Observations & 1704 & 1704 & 1704 & 1704 & 1704 & 1704 \\
\hline Panels & 156 & 156 & 156 & 156 & 156 & 156 \\
\hline R-squared & 0.65 & 0.64 & 0.64 & 0.61 & 0.59 & 0.54 \\
\hline
\end{tabular}

OLS, robust standard errors in brackets

* significant at $10 \%$; ** significant at $5 \%$; *** significant at $1 \%$

Country pair fixed effects, controls for Single Market participation and common year effects 
Table A4 Robustness check: Exclusion of individual countries (sample of 20 OECD countries)

\begin{tabular}{|c|c|c|c|c|c|c|c|c|c|c|c|}
\hline & Total & Austria & Belgium & Finland & France & Germany & Ireland & Italy & Holland & Portugal & Spain \\
\hline \multirow[t]{2}{*}{ EZ11p1 } & $0.165^{\star \star \star}$ & $0.154^{\star \star \star}$ & & $0.165^{\star \star \star}$ & $0.163^{\star \star \star}$ & $0.168^{\star \star \star}$ & $0.146^{\star \star \star}$ & $0.166^{\star \star \star}$ & $0.189^{\star \star \star}$ & $0.208^{\star \star \star}$ & $0.155^{\star \star \star}$ \\
\hline & [0.023] & [0.024] & [0.024] & {$[0.024]$} & {$[0.024]$} & {$[0.025]$} & [0.022] & {$[0.025]$} & [0.024] & [0.024] & [0.024] \\
\hline \multirow[t]{2}{*}{ EZ11p2 } & $0.232^{\star \star \star}$ & $0.221^{\star \star \star}$ & $0.200^{\star \star \star}$ & $0.248^{\star \star \star}$ & $0.238^{\star \star \star}$ & $0.234^{\star \star \star}$ & $0.218^{\star \star \star \star}$ & $0.234^{\star \star \star}$ & $0.241^{\star \star \star}$ & $0.267^{\star \star \star}$ & $0.216^{\star \star \star \star}$ \\
\hline & {$[0.024]$} & {$[0.024]$} & [0.024] & {$[0.024]$} & {$[0.025]$} & {$[0.025]$} & [0.023] & {$[0.025]$} & [0.024] & [0.024] & {$[0.025]$} \\
\hline \multirow[t]{2}{*}{ EZ10p1 } & $0.074^{\star \star \star}$ & $0.065^{\star \star \star}$ & $0.069^{\star \star \star \star}$ & $0.082^{\star \star \star}$ & $0.072^{\star \star \star}$ & $0.072^{\star \star \star}$ & $0.064^{\star \star \star}$ & $0.085^{\star \star \star}$ & $0.070^{* \star *}$ & $0.112^{\star \star \star}$ & $0.068^{\star \star \star}$ \\
\hline & {$[0.020]$} & [0.021] & [0.021] & {$[0.021]$} & {$[0.021]$} & {$[0.021]$} & {$[0.020]$} & [0.021] & {$[0.021]$} & {$[0.020]$} & [0.021] \\
\hline \multirow[t]{2}{*}{ EZ10p2 } & $0.113^{\star \star \star}$ & $0.092^{\star \star \star}$ & $0.097^{\star \star \star}$ & $0.135^{\star \star \star}$ & $0.114^{\star \star \star}$ & $0.106^{\star \star \star}$ & $0.117^{\star \star \star}$ & $0.125^{\star \star \star}$ & $0.097^{\star \star \star}$ & $0.156^{\star \star \star}$ & $0.107^{\star \star \star}$ \\
\hline & [0.022] & [0.023] & [0.023] & [0.023] & [0.023] & [0.023] & [0.022] & [0.023] & {$[0.023]$} & [0.022] & [0.023] \\
\hline \multirow[t]{2}{*}{ EZ01p1 } & $0.085^{\star \star \star}$ & $0.085^{\star \star \star}$ & $0.086^{\star \star \star}$ & $0.093^{\star \star \star}$ & $0.080^{\star \star *}$ & $0.089^{\star \star \star}$ & $0.070^{\star \star \star}$ & $0.085^{\star \star \star}$ & $0.084^{\star \star \star}$ & $0.102^{\star \star \star}$ & $0.081^{\star \star \star}$ \\
\hline & {$[0.025]$} & {$[0.025]$} & {$[0.026]$} & {$[0.026]$} & {$[0.026]$} & {$[0.026]$} & {$[0.025]$} & {$[0.026]$} & {$[0.026]$} & [0.025] & [0.025] \\
\hline \multirow[t]{2}{*}{ EZ01p2 } & $0.120^{\star \star \star}$ & $0.119^{\star \star \star}$ & $0.114^{\star \star \star}$ & $0.125^{\star \star \star}$ & $0.115^{\star \star \star}$ & $0.125^{\star \star \star}$ & $0.109^{\star \star \star}$ & $0.122^{\star \star \star}$ & $0.115^{\star \star \star}$ & $0.128^{\star \star \star}$ & $0.110^{\star \star \star}$ \\
\hline & {$[0.026]$} & {$[0.026]$} & {$[0.026]$} & {$[0.026]$} & {$[0.026]$} & {$[0.027]$} & {$[0.026]$} & {$[0.026]$} & {$[0.026]$} & {$[0.026]$} & {$[0.026]$} \\
\hline \multirow[t]{2}{*}{ InRGDPx } & $0.590^{\star \star \star}$ & $0.628^{\star \star \star}$ & $0.528^{\star \star \star}$ & $0.689 * \star \star$ & $0.612^{\star \star \star}$ & $0.653^{\star \star \star}$ & 0.166 & $0.529 * \star \star$ & $0.624^{\star \star \star}$ & $0.496^{\star \star \star}$ & $0.595^{\star \star \star}$ \\
\hline & {$[0.089]$} & [0.093] & [0.081] & [0.093] & [0.093] & {$[0.096]$} & {$[0.102]$} & [0.099] & {$[0.093]$} & [0.093] & {$[0.097]$} \\
\hline \multirow[t]{2}{*}{ InRGDPx } & $1.185^{\star \star \star}$ & $1.192^{\star \star \star}$ & $1.147^{\star \star \star}$ & $1.259^{\star \star \star \star}$ & $1.175^{\star \star \star}$ & $1.149^{\star \star \star}$ & $1.426^{\star \star *}$ & $1.204^{\star \star \star}$ & $1.185^{\star \star \star}$ & $1.144^{\star \star \star}$ & $1.131^{\star \star \star}$ \\
\hline & {$[0.078]$} & [0.082] & {$[0.079]$} & {$[0.081]$} & {$[0.083]$} & {$[0.087]$} & [0.101] & {$[0.086]$} & [0.082] & {$[0.081]$} & [0.085] \\
\hline \multirow[t]{2}{*}{ InREXRxm } & $-0.189^{\star \star \star}$ & $-0.213^{\star \star \star}$ & $-0.157^{\star \star}$ & $-0.231^{\star \star \star}$ & $-0.178^{\star \star}$ & $-0.192^{\star \star \star}$ & $-0.163^{\star \star}$ & $-0.130^{\star}$ & $-0.205^{\star \star \star}$ & $-0.128^{*}$ & $-0.162^{\star \star}$ \\
\hline & {$[0.066]$} & [0.069] & [0.069] & {$[0.070]$} & {$[0.070]$} & {$[0.070]$} & {$[0.067]$} & [0.071] & {$[0.069]$} & {$[0.070]$} & {$[0.069]$} \\
\hline \multirow[t]{2}{*}{ InREXRcm } & $-0.297^{\star \star \star}$ & $-0.270^{\star \star \star}$ & $-0.344^{\star \star \star}$ & $-0.259^{\star \star \star}$ & $-0.301^{\star \star \star}$ & $-0.289^{\star \star \star}$ & $-0.286^{\star \star \star}$ & $-0.365^{\star \star \star}$ & $-0.292^{\star \star \star}$ & $-0.395^{\star \star \star}$ & $-0.313^{\star \star \star}$ \\
\hline & [0.094] & [0.098] & [0.100] & [0.098] & {$[0.100]$} & {$[0.099]$} & {$[0.096]$} & [0.100] & [0.098] & [0.098] & {$[0.097]$} \\
\hline \multirow[t]{2}{*}{ InREXRxm-1 } & $-0.605^{\star \star \star}$ & $-0.568^{\star \star \star *}$ & $-0.592^{\star \star \star}$ & $-0.607^{\star \star \star \star}$ & $-0.635^{\star \star \star}$ & $-0.608 * \star \star$ & $-0.613^{\star \star \star}$ & $-0.612^{\star \star \star}$ & $-0.608^{\star \star \star}$ & $-0.537^{\star \star \star}$ & $-0.634^{\star \star \star}$ \\
\hline & {$[0.067]$} & [0.069] & [0.070] & [0.069] & [0.071] & {$[0.070]$} & [0.066] & {$[0.073]$} & [0.069] & {$[0.069]$} & {$[0.069]$} \\
\hline \multirow{2}{*}{ InREXRcm-1 } & $0.392^{\star \star \star}$ & $0.360^{\star \star \star}$ & $0.341^{\star \star \star}$ & $0.413^{\star \star \star}$ & $0.409^{\star * \star}$ & $0.393^{\star \star \star}$ & $0.406^{\star \star \star}$ & $0.413^{\star \star \star}$ & $0.402^{\star \star \star}$ & $0.319^{\star \star \star}$ & $0.409^{\star \star \star}$ \\
\hline & [0.091] & {$[0.094]$} & [0.095] & [0.094] & [0.096] & {$[0.096]$} & [0.088] & [0.100] & {$[0.095]$} & [0.093] & [0.094] \\
\hline Observations & 4161 & 3744 & 3744 & 3744 & 3744 & 3744 & 3744 & 3744 & 3744 & 3762 & 3744 \\
\hline Panels & 380 & 342 & 342 & 342 & 342 & 342 & 342 & 342 & 342 & 342 & 342 \\
\hline R-squared & 0.53 & 0.51 & 0.50 & 0.54 & 0.51 & 0.51 & 0.50 & 0.52 & 0.52 & 0.55 & 0.49 \\
\hline
\end{tabular}

OLS, robust standard errors in brackets

* significant at 10\%; ** significant at $5 \%$; *** significant at $1 \%$ 
Denmark Swew

\begin{tabular}{|c|c|c|c|c|c|c|c|c|c|c|}
\hline EZ11p1 & $\begin{array}{l}0.224^{\star \star \star} \\
{[0.025]}\end{array}$ & $\begin{array}{l}0.140 * \star \star \\
{[0.029]}\end{array}$ & $\begin{array}{l}0.148^{\star * *} \\
{[0.028]}\end{array}$ & $\begin{array}{l}0.155^{\star \star *} \\
{[0.027]}\end{array}$ & $\begin{array}{l}0.149 * \star * \\
{[0.025]}\end{array}$ & $\begin{array}{l}0.157^{* \star \star} \\
{[0.023]}\end{array}$ & $\begin{array}{l}0.194^{\star \star \star} \\
{[0.023]}\end{array}$ & $\begin{array}{l}0.171^{\star \star \star} \\
{[0.025]}\end{array}$ & $\begin{array}{l}0.139 * \star * \\
{[0.023]}\end{array}$ & $\begin{array}{l}0.152^{\star \star \star} \\
{[0.025]}\end{array}$ \\
\hline \multirow[t]{2}{*}{ EZ11p2 } & 0.330 *** & $0.219 * \star \star$ & $0.181^{\star \star \star}$ & $0.215^{\star \star \star}$ & $0.206^{\star \star \star}$ & 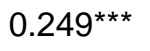 & $0.258^{\star * *}$ & $0.228^{\star \star \star}$ & $0.221^{\star \star \star}$ & 0.220 *** \\
\hline & [0.027] & [0.030] & [0.029] & [0.027] & [0.025] & [0.023] & [0.025] & [0.025] & [0.023] & [0.025] \\
\hline \multirow[t]{2}{*}{ EZ10p1 } & $0.133^{\star \star *}$ & 0.042 & $0.056^{\star \star}$ & $0.068^{\star \star \star}$ & $0.053^{\star * *}$ & $0.071^{\star \star *}$ & $0.102^{* * *}$ & $0.085^{\star \star \star}$ & $0.046^{\star \star}$ & $0.065^{\star \star \star}$ \\
\hline & [0.023] & [0.025] & [0.026] & [0.022] & [0.022] & [0.021] & [0.021] & [0.022] & [0.020] & [0.022] \\
\hline \multirow[t]{2}{*}{ EZ10p2 } & $0.205^{\star \star \star}$ & $0.081^{\star * *}$ & $0.064^{\star \star}$ & $0.117^{* \star *}$ & $0.082^{* * *}$ & $0.121^{\star \star \star}$ & $0.136^{\star * *}$ & $0.112^{\star \star \star}$ & $0.092^{\star \star *}$ & $0.105^{\star \star *}$ \\
\hline & [0.025] & [0.028] & [0.028] & [0.024] & [0.024] & [0.023] & [0.024] & [0.025] & [0.021] & [0.024] \\
\hline \multirow[t]{2}{*}{ EZ01p1 } & $0.128^{\star \star \star *}$ & $0.072^{\star \star}$ & $0.068 * \star$ & 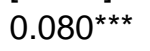 & 0.070 ** & $0.071^{\star \star *}$ & $0.127^{\star \star \star}$ & $0.088^{\star \star \star}$ & $0.070^{\star \star \star}$ & $0.076^{\star * \star}$ \\
\hline & [0.025] & [0.032] & [0.032] & [0.030] & [0.028] & [0.023] & [0.024] & [0.027] & [0.026] & [0.027] \\
\hline \multirow[t]{2}{*}{ EZ01p2 } & 0.170 *** & $0.102^{\star \star \star}$ & $0.103^{\star \star \star}$ & $0.117^{\star \star \star}$ & $0.091^{\star \star \star}$ & $0.147^{\star \star \star}$ & $0.153^{\star \star \star}$ & $0.107^{\star \star \star}$ & $0.123^{\star \star \star}$ & $0.106^{\star \star \star}$ \\
\hline & [0.028] & [0.033] & [0.033] & [0.029] & [0.028] & [0.025] & [0.027] & [0.028] & [0.024] & [0.028] \\
\hline \multirow[t]{2}{*}{ InRGDPx } & $0.631^{\star \star *}$ & $0.626^{\star \star \star}$ & $0.621^{\star \star \star}$ & 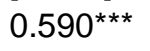 & $0.583^{\star \star \star}$ & $0.586 * \star \star$ & $0.680^{\star \star \star}$ & $0.537^{\star \star \star}$ & $0.594^{\star \star \star}$ & $0.554^{\star \star *}$ \\
\hline & [0.092] & [0.094] & [0.093] & [0.092] & [0.090] & [0.093] & [0.090] & [0.099] & [0.095] & [0.090] \\
\hline \multirow[t]{2}{*}{ InRGDPx } & $1.139 * \star \star$ & 1.239 *** & $1.195^{\star \star \star ~}$ & $1.161^{\star \star \star}$ & $1.131^{\star \star \star}$ & 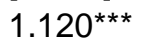 & $1.184^{\star \star \star}$ & $1.219 * \star \star$ & $1.280^{\star \star \star}$ & $1.183^{\star \star \star}$ \\
\hline & [0.077] & [0.081] & [0.082] & [0.081] & [0.081] & [0.079] & [0.082] & [0.084] & [0.081] & [0.083] \\
\hline \multirow[t]{2}{*}{ InREXRxm } & $-0.218^{\star \star \star}$ & $-0.230^{\star \star \star}$ & $-0.181^{\star \star}$ & $-0.196^{\star \star \star}$ & -0.094 & $-0.116^{\star}$ & $-0.193^{\star \star \star}$ & $-0.261^{\star \star \star}$ & 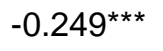 & $-0.260^{\star \star \star \star}$ \\
\hline & [0.066] & [0.071] & [0.076] & [0.069] & [0.072] & [0.066] & [0.068] & [0.078] & {$[0.076]$} & [0.074] \\
\hline \multirow[t]{2}{*}{ InREXRcm } & $-0.263^{\star \star *}$ & $-0.247^{* \star}$ & $-0.344^{\star \star *}$ & $-0.292^{* \star *}$ & $-0.376^{\star \star *}$ & $-0.286^{\star \star *}$ & $-0.303^{\star * *}$ & $-0.227^{\star \star}$ & $-0.276^{\star \star \star}$ & $-0.224^{\star *}$ \\
\hline & [0.096] & [0.098] & [0.107] & [0.094] & [0.104] & [0.096] & [0.097] & [0.109] & [0.102] & [0.105] \\
\hline \multirow[t]{2}{*}{ InREXRxm-1 } & $-0.588^{\star \star \star}$ & $-0.592^{\star \star \star}$ & $-0.611^{\star \star \star}$ & $-0.592^{\star \star \star}$ & $-0.708^{\star \star \star}$ & $-0.666^{\star \star \star}$ & $-0.555^{\star \star \star}$ & $-0.548^{\star \star \star}$ & $-0.624^{\star \star \star}$ & $-0.576^{\star \star \star}$ \\
\hline & {$[0.067]$} & [0.071] & [0.078] & {$[0.070]$} & [0.072] & [0.064] & [0.068] & [0.078] & [0.075] & {$[0.076]$} \\
\hline \multirow[t]{2}{*}{ InREXRcm-1 } & $0.378^{\star * *}$ & $0.379 * \star \star$ & $0.387^{* * *}$ & $0.330^{* * *}$ & $0.477^{* * *}$ & $0.392^{\star \star \star}$ & $0.367^{\star \star \star}$ & $0.327^{\star \star \star}$ & $0.473^{\star \star \star}$ & $0.456^{\star * \star}$ \\
\hline & [0.092] & {$[0.097]$} & [0.105] & [0.093] & [0.103] & [0.092] & [0.094] & [0.105] & [0.100] & [0.103] \\
\hline Observations & 3744 & 3744 & 3744 & 3744 & 3744 & 3744 & 3744 & 3744 & 3744 & 3744 \\
\hline Panels & 342 & 342 & 342 & 342 & 342 & 342 & 342 & 342 & 342 & 342 \\
\hline R-squared & 0.55 & 0.53 & 0.53 & 0.55 & 0.54 & 0.55 & 0.54 & 0.53 & 0.55 & 0.51 \\
\hline
\end{tabular}

Country pair fixed effects

Controls for deviation from trend GDP, Single Market participation and common year effects 
Table A5 Robustness check: Exclusion of individual countries (sample of 13 EU countries)

\begin{tabular}{|c|c|c|c|c|c|c|c|c|c|c|c|}
\hline & Total & Austria & Belgium & Finland & France & Germany & Ireland & Italy & Holland & Portugal & Spain \\
\hline \multirow[t]{2}{*}{ EZ11p1 } & $0.114^{\star \star \star}$ & $0.109^{\star \star \star}$ & $0.122^{\star \star \star}$ & $0.108^{\star \star \star}$ & $0.108^{\star \star \star}$ & $0.118^{\star \star \star}$ & $0.091^{\star \star \star}$ & $0.107^{\star \star \star}$ & $0.144^{\star \star \star}$ & $0.149^{\star \star \star}$ & $0.095^{\star \star \star}$ \\
\hline & [0.032] & [0.033] & [0.034] & {$[0.033]$} & {$[0.033]$} & {$[0.033]$} & [0.031] & [0.034] & [0.033] & [0.032] & [0.033] \\
\hline \multirow[t]{2}{*}{ EZ11p2 } & $0.187^{\star \star \star}$ & $0.188^{\star \star \star}$ & $0.174^{\star \star \star}$ & $0.206^{\star \star \star}$ & $0.203^{\star \star \star}$ & $0.189^{\star \star \star}$ & $0.181^{\star \star \star}$ & $0.182^{\star \star \star}$ & $0.194^{\star \star \star}$ & $0.199^{\star \star \star}$ & $0.155^{\star \star \star \star}$ \\
\hline & {$[0.037]$} & {$[0.038]$} & [0.038] & {$[0.038]$} & {$[0.038]$} & {$[0.038]$} & [0.035] & {$[0.038]$} & {$[0.037]$} & {$[0.037]$} & [0.038] \\
\hline \multirow[t]{2}{*}{ EZ10p1 } & 0.032 & 0.024 & 0.030 & 0.038 & 0.023 & 0.029 & 0.020 & 0.039 & 0.035 & $0.082^{\star *}$ & 0.015 \\
\hline & [0.033] & [0.034] & [0.034] & [0.034] & [0.034] & [0.034] & [0.033] & [0.034] & [0.034] & [0.032] & [0.033] \\
\hline \multirow[t]{2}{*}{ EZ10p2 } & 0.052 & 0.030 & 0.050 & $0.072^{*}$ & 0.058 & 0.037 & $0.069^{\star}$ & 0.059 & 0.045 & $0.090^{* *}$ & 0.026 \\
\hline & [0.039] & [0.040] & {$[0.040]$} & [0.040] & {$[0.040]$} & [0.040] & {$[0.037]$} & [0.040] & [0.039] & [0.038] & [0.039] \\
\hline \multirow[t]{2}{*}{ EZ01p1 } & 0.053 & 0.053 & $0.066^{*}$ & 0.051 & 0.048 & $0.058^{*}$ & 0.039 & 0.042 & $0.067^{\star}$ & $0.059^{\star}$ & 0.043 \\
\hline & [0.033] & {$[0.034]$} & [0.035] & {$[0.034]$} & [0.035] & [0.034] & {$[0.033]$} & [0.034] & {$[0.035]$} & [0.033] & [0.034] \\
\hline \multirow[t]{2}{*}{ EZ01p2 } & $0.086^{\star \star}$ & $0.092^{\star \star}$ & $0.094^{\star \star}$ & $0.090^{\star \star}$ & $0.087^{\star \star}$ & $0.092^{\star \star}$ & $0.084^{\star \star}$ & $0.074^{*}$ & $0.100^{* *}$ & $0.078^{\star \star}$ & 0.063 \\
\hline & {$[0.040]$} & {$[0.042]$} & {$[0.042]$} & {$[0.042]$} & {$[0.042]$} & {$[0.042]$} & [0.039] & {$[0.042]$} & [0.041] & {$[0.039]$} & {$[0.041]$} \\
\hline \multirow[t]{2}{*}{ InRGDPx } & $0.603^{\star \star \star}$ & $0.643^{\star \star \star}$ & $0.432^{\star \star \star}$ & $0.740^{\star \star \star}$ & $0.607^{\star \star \star}$ & $0.687^{\star \star \star}$ & -0.084 & $0.490^{\star \star \star}$ & $0.637^{\star \star \star}$ & $0.509^{\star \star \star}$ & $0.540^{\star \star \star}$ \\
\hline & {$[0.117]$} & [0.127] & [0.084] & [0.123] & {$[0.127]$} & [0.133] & [0.138] & {$[0.135]$} & {$[0.125]$} & [0.126] & [0.142] \\
\hline \multirow[t]{2}{*}{ InRGDPx } & $1.198^{\star \star \star}$ & $1.237^{\star \star \star}$ & $1.145^{\star \star \star}$ & $1.308^{\star \star \star}$ & $1.185^{\star \star \star}$ & $1.131^{\star \star *}$ & $1.154^{\star \star \star *}$ & $1.289^{\star \star \star}$ & $1.149^{\star \star \star}$ & $1.218^{\star \star \star}$ & $1.081^{\star \star \star}$ \\
\hline & [0.104] & [0.113] & [0.105] & [0.108] & {$[0.114]$} & [0.122] & [0.142] & [0.119] & [0.111] & [0.107] & [0.121] \\
\hline \multirow[t]{2}{*}{ InREXRxm } & $-0.320^{\star \star \star}$ & $-0.330^{\star \star \star}$ & $-0.306^{\star \star \star}$ & $-0.404^{\star \star \star}$ & $-0.334^{\star \star \star}$ & $-0.356^{\star \star \star}$ & $-0.321^{\star \star \star}$ & $-0.297^{\star *}$ & $-0.320^{\star \star \star}$ & -0.160 & $-0.350^{\star \star \star}$ \\
\hline & {$[0.113]$} & [0.122] & [0.113] & [0.118] & [0.126] & [0.123] & [0.098] & [0.132] & [0.117] & [0.129] & [0.123] \\
\hline \multirow[t]{2}{*}{ InREXRcm } & -0.161 & -0.157 & -0.147 & -0.018 & -0.173 & -0.083 & -0.061 & -0.204 & $-0.270^{\star}$ & $-0.396^{\star *}$ & -0.074 \\
\hline & [0.153] & [0.163] & [0.171] & [0.161] & {$[0.170]$} & [0.167] & {$[0.142]$} & [0.174] & {$[0.159]$} & {$[0.167]$} & [0.166] \\
\hline \multirow[t]{2}{*}{ InREXRxm-1 } & $-0.595^{\star \star \star}$ & $-0.500^{\star \star \star *}$ & $-0.577^{\star \star \star}$ & $-0.573^{\star \star \star}$ & $-0.702^{\star \star \star}$ & 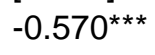 & $-0.677^{\star \star \star \star}$ & $-0.571^{\star \star \star}$ & $-0.633^{\star \star *}$ & $-0.469 * \star \star$ & $-0.640^{\star \star \star}$ \\
\hline & [0.108] & [0.115] & [0.114] & [0.113] & {$[0.120]$} & [0.117] & {$[0.096]$} & [0.132] & [0.112] & [0.116] & [0.114] \\
\hline \multirow[t]{2}{*}{ InREXRcm-1 } & $0.464^{\star \star \star}$ & $0.388^{* *}$ & $0.299^{\star}$ & $0.393^{\star \star}$ & $0.606^{\star \star \star}$ & $0.430^{* *}$ & $0.493^{\star \star \star}$ & $0.544^{\star \star \star}$ & $0.578^{\star * \star}$ & $0.409^{\star *}$ & $0.520^{\star \star \star}$ \\
\hline & {$[0.157]$} & [0.171] & [0.170] & [0.168] & [0.174] & [0.172] & [0.141] & [0.191] & {$[0.164]$} & [0.164] & {$[0.169]$} \\
\hline Observations & 1704 & 1441 & 1441 & 1441 & 1441 & 1441 & 1441 & 1441 & 1441 & 1452 & 1441 \\
\hline Panels & 156 & 132 & 132 & 132 & 132 & 132 & 132 & 132 & 132 & 132 & 132 \\
\hline R-squared & 0.65 & 0.64 & 0.64 & 0.67 & 0.64 & 0.64 & 0.68 & 0.64 & 0.67 & 0.69 & 0.59 \\
\hline
\end{tabular}

OLS, robust standard errors in brackets

* significant at 10\%; ** significant at $5 \%$; *** significant at $1 \%$ 
Denmark Sweden U.K.

\begin{tabular}{|c|c|c|c|}
\hline EZ11p1 & $\begin{array}{l}0.261^{\star \star \star} \\
{[0.035]}\end{array}$ & $\begin{array}{l}0.048 \\
{[0.037]}\end{array}$ & $\begin{array}{l}0.030 \\
{[0.047]}\end{array}$ \\
\hline \multirow[t]{2}{*}{ EZ11p2 } & $0.425^{\star \star \star}$ & $0.137^{\star \star}$ & -0.001 \\
\hline & {$[0.027]$} & {$[0.057]$} & [0.035] \\
\hline \multirow[t]{2}{*}{ EZ10p1 } & $0.193^{\star \star \star}$ & -0.038 & -0.061 \\
\hline & {$[0.036]$} & {$[0.038]$} & [0.049] \\
\hline \multirow[t]{2}{*}{ EZ10p2 } & $0.305^{\star \star \star}$ & -0.006 & $-0.141^{* *}$ \\
\hline & [0.031] & [0.059] & [0.039] \\
\hline \multirow[t]{2}{*}{ EZ01p1 } & $0.161^{\star \star \star}$ & 0.031 & -0.033 \\
\hline & [0.035] & [0.039] & {$[0.050]$} \\
\hline \multirow[t]{2}{*}{ EZ01p2 } & $0.232^{\star \star \star}$ & 0.067 & -0.040 \\
\hline & {$[0.030]$} & [0.063] & [0.042] \\
\hline \multirow[t]{2}{*}{ InRGDPx } & $0.754^{\star \star \star}$ & $0.653^{\star \star \star}$ & $0.695^{\star \star \star}$ \\
\hline & [0.125] & [0.128] & [0.126] \\
\hline \multirow[t]{2}{*}{ InRGDPx } & $1.085^{\star \star \star}$ & $1.326^{\star \star \star}$ & $1.217^{\star \star \star}$ \\
\hline & {$[0.091]$} & [0.106] & [0.113] \\
\hline \multirow[t]{2}{*}{ InREXRxm } & $-0.389^{\star \star \star}$ & $-0.320^{\star *}$ & $-0.264^{\star}$ \\
\hline & {$[0.117]$} & [0.130] & [0.159] \\
\hline \multirow[t]{2}{*}{ InREXRcm } & -0.075 & -0.204 & -0.239 \\
\hline & [0.157] & [0.173] & {$[0.220]$} \\
\hline \multirow[t]{2}{*}{ InREXRxm-1 } & $-0.462^{\star \star \star}$ & $-0.640^{\star \star \star}$ & $-0.581^{\star *}$ \\
\hline & [0.112] & [0.125] & {$[0.157]$} \\
\hline \multirow[t]{2}{*}{ InREXRcm-1 } & $0.357^{* *}$ & $0.500 * \star \star$ & 0.362 \\
\hline & [0.161] & [0.180] & [0.239] \\
\hline Observations & 1441 & 1441 & 1441 \\
\hline Panels & 132 & 132 & 132 \\
\hline R-squared & 0.68 & 0.65 & 0.66 \\
\hline
\end{tabular}

Country pair fixed effects

Controls for deviation from trend GDP, Single Market participation and common year effects 


\begin{tabular}{|c|c|c|c|c|c|c|c|c|c|c|c|c|c|}
\hline & Total & $01-05$ & $10-12$ & $\begin{array}{l}13- \\
14\end{array}$ & $15-16$ & $17-19$ & 20 & 21 & 22 & 23 & $\begin{array}{l}24- \\
2423\end{array}$ & 2423 & 25 \\
\hline EZ11p1 & $\begin{array}{l}0.165^{\star \star \star} \\
{[0.023]}\end{array}$ & $\begin{array}{l}0.062 \\
{[0.090]}\end{array}$ & $\begin{array}{l}-0.881^{\star \star} \\
{[0.432]}\end{array}$ & $\begin{array}{l}-0.112 \\
{[0.223]}\end{array}$ & $\begin{array}{l}0.069^{\star} \\
{[0.036]}\end{array}$ & $\begin{array}{l}0.011 \\
{[0.039]}\end{array}$ & $\begin{array}{l}0.289 * \star \\
{[0.143]}\end{array}$ & $\begin{array}{l}0.165 \\
{[0.140]}\end{array}$ & & & & $\begin{array}{l}0.265^{\star \star \star} \\
{[0.074]}\end{array}$ & $\begin{array}{l}0.198^{\star \star \star} \\
{[0.041]}\end{array}$ \\
\hline EZ11p2 & $\begin{array}{l}0.232^{\star \star \star *} \\
{[0.024]}\end{array}$ & $\begin{array}{l}0.092 \\
{[0.082]}\end{array}$ & $\begin{array}{l}0.772^{\star} \\
{[0.395]}\end{array}$ & $\begin{array}{l}0.010 \\
{[0.204]}\end{array}$ & $\begin{array}{l}0.050 \\
{[0.038]}\end{array}$ & $\begin{array}{l}0.027 \\
{[0.042]}\end{array}$ & $\begin{array}{l}0.422^{\star \star \star *} \\
{[0.134]}\end{array}$ & $\begin{array}{l}0.169 \\
{[0.129]}\end{array}$ & $\begin{array}{l}0.116^{\star *} \\
{[0.055]}\end{array}$ & $\begin{array}{l}0.135 \\
{[0.334]}\end{array}$ & $\begin{array}{l}0.178^{\star \star \star \star} \\
{[0.066]}\end{array}$ & $\begin{array}{l}0.586^{\star \star \star} \\
{[0.079]}\end{array}$ & $\begin{array}{l}0.169^{\star \star \star} \\
{[0.040]}\end{array}$ \\
\hline EZ10p1 & $\begin{array}{l}0.074^{\star \star \star} \\
{[0.020]}\end{array}$ & $\begin{array}{l}0.002 \\
{[0.093]}\end{array}$ & $\begin{array}{l}-0.491 \\
{[0.393]}\end{array}$ & $\begin{array}{l}0.013 \\
{[0.222]}\end{array}$ & $\begin{array}{l}-0.009 \\
{[0.035]}\end{array}$ & $\begin{array}{l}-0.029 \\
{[0.035]}\end{array}$ & $\begin{array}{l}0.066 \\
{[0.136]}\end{array}$ & $\begin{array}{l}-0.016 \\
{[0.116]}\end{array}$ & $\begin{array}{l}0.119^{\star \star \star \star} \\
{[0.046]}\end{array}$ & $\begin{array}{l}-0.318 \\
{[0.342]}\end{array}$ & $\begin{array}{l}-0.012 \\
{[0.047]}\end{array}$ & $\begin{array}{l}0.211^{\star * \star} \\
{[0.067]}\end{array}$ & $\begin{array}{l}0.122^{\star * *} \\
{[0.039]}\end{array}$ \\
\hline EZ10p2 & $\begin{array}{l}0.113^{\star \star \star} \\
{[0.022]}\end{array}$ & $\begin{array}{l}0.115 \\
{[0.089]}\end{array}$ & $\begin{array}{l}0.463 \\
{[0.393]}\end{array}$ & $\begin{array}{l}-0.021 \\
{[0.184]}\end{array}$ & $\begin{array}{l}-0.009 \\
{[0.035]}\end{array}$ & $\begin{array}{l}-0.083^{\star *} \\
{[0.037]}\end{array}$ & $\begin{array}{l}0.307^{\star \star} \\
{[0.122]}\end{array}$ & $\begin{array}{l}-0.046 \\
{[0.108]}\end{array}$ & $\begin{array}{l}0.011 \\
{[0.049]}\end{array}$ & $\begin{array}{l}0.237 \\
{[0.322]}\end{array}$ & $\begin{array}{l}-0.027 \\
{[0.053]}\end{array}$ & $\begin{array}{l}0.386^{\star \star \star \star} \\
{[0.071]}\end{array}$ & $\begin{array}{l}0.109^{\star \star \star} \\
{[0.036]}\end{array}$ \\
\hline EZ01p1 & $\begin{array}{l}0.085^{\star \star \star} \\
{[0.025]}\end{array}$ & $\begin{array}{l}-0.008 \\
{[0.070]}\end{array}$ & $\begin{array}{l}-0.106 \\
{[0.405]}\end{array}$ & $\begin{array}{l}-0.294 \\
{[0.263]}\end{array}$ & $\begin{array}{l}0.040 \\
{[0.037]}\end{array}$ & $\begin{array}{l}0.004 \\
{[0.045]}\end{array}$ & $\begin{array}{l}0.245 \\
{[0.178]}\end{array}$ & $\begin{array}{l}0.101 \\
{[0.186]}\end{array}$ & $\begin{array}{l}-0.072 \\
{[0.069]}\end{array}$ & $\begin{array}{l}-0.007 \\
{[0.362]}\end{array}$ & $\begin{array}{l}0.086 \\
{[0.084]}\end{array}$ & $\begin{array}{l}0.095 \\
{[0.088]}\end{array}$ & $\begin{array}{l}0.202^{\star \star \star} \\
{[0.046]}\end{array}$ \\
\hline EZ01p2 & $\begin{array}{l}0.120^{\star \star \star} \\
{[0.026]}\end{array}$ & $\begin{array}{l}-0.044 \\
{[0.066]}\end{array}$ & $\begin{array}{l}0.540 \\
{[0.368]}\end{array}$ & $\begin{array}{l}-0.165 \\
{[0.238]}\end{array}$ & $\begin{array}{l}-0.096^{\star \star} \\
{[0.039]}\end{array}$ & $\begin{array}{l}-0.086^{*} \\
{[0.048]}\end{array}$ & $\begin{array}{l}0.343^{*} \\
{[0.177]}\end{array}$ & $\begin{array}{l}0.121 \\
{[0.161]}\end{array}$ & $\begin{array}{l}-0.130^{\star \star} \\
{[0.061]}\end{array}$ & $\begin{array}{l}0.268 \\
{[0.341]}\end{array}$ & $\begin{array}{l}0.253^{\star \star \star} \\
{[0.090]}\end{array}$ & $\begin{array}{l}0.345^{\star \star \star} \\
{[0.095]}\end{array}$ & $\begin{array}{l}0.143^{\star \star \star} \\
{[0.044]}\end{array}$ \\
\hline Observations & 4161 & 4161 & 4161 & 4161 & 4161 & 4161 & 4161 & 4161 & 4161 & 4161 & 4161 & 4161 & 4161 \\
\hline Panels & 380 & 380 & 380 & 380 & 380 & 380 & 380 & 380 & 380 & 380 & 380 & 380 & 380 \\
\hline R-squared & 0.53 & 0.07 & 0.03 & 0.02 & 0.38 & 0.20 & 0.11 & 0.08 & 0.14 & 0.31 & 0.15 & 0.35 & 0.25 \\
\hline
\end{tabular}

Legends

01-05

$10-12$

$13-14$

$15-16$

$17-19$

20

21

22

23

$24-2423$

2423

25

AGRICULTURE, HUNTING, FORESTRY AND FISHING

MINING AND QUARRYING OF ENERGY PRODUCING MATERIALS

MINING AND OUARRYING EXCEPT ENERGY PRODUCING MATERIALS

FOOD PRODUCTS, BEVERAGES AND TOBACCO

TEXTILES, TEXTILE PRODUCTS, LEATHER AND FOOTWEAR

WOOD AND PRODUCTS OF WOOD AND CORK

PULP, PAPER AND PAPER PRODUCTS

PRINTING AND PUBLISHING

COKE, REFINED PETROLEUM PRODUCTS AND NUCLEAR FUEL

CHEMICALS EXCLUDING PHARMACEUTICALS

PHARMACEUTICALS

RUBBER AND PLASTICS PRODUCTS 


\begin{tabular}{|c|c|c|c|c|c|c|c|c|c|c|c|}
\hline & 26 & 27 & 28 & 29 & 30 & 31 & 32 & 33 & 34 & 35 & 36 \\
\hline EZ11p1 & 0.158 & $0.286^{\star *}$ & $0.181^{\star \star \star}$ & $0.183^{\star * *}$ & 0.097 & $0.135^{\star \star \star}$ & $0.153^{\star *}$ & $0.127^{\star * *}$ & 0.221 & 0.221 & $\begin{array}{l}0.143^{\star * *} \\
{[0.055]}\end{array}$ \\
\hline EZ11p2 & $\begin{array}{l}{[0.106]} \\
0.254^{\star \star \star}\end{array}$ & $\begin{array}{l}{[0.118]} \\
0.210^{\star}\end{array}$ & $\begin{array}{l}{[0.040]} \\
0.310^{\star \star \star}\end{array}$ & $\begin{array}{l}{[0.031]} \\
0.253^{\star \star \star}\end{array}$ & $\begin{array}{l}{[0.077]} \\
0.084\end{array}$ & $\begin{array}{l}{[0.046]} \\
0.150^{\star * \star}\end{array}$ & $\begin{array}{l}{[0.073]} \\
0.351^{\star \star \star}\end{array}$ & $\begin{array}{l}{[0.038]} \\
0.166^{\star \star \star}\end{array}$ & $\begin{array}{l}{[0.151]} \\
0.482^{\star \star \star}\end{array}$ & $\begin{array}{l}{[0.151]} \\
0.482^{\star \star \star}\end{array}$ & $0.151^{\star \star \star}$ \\
\hline & {$[0.091]$} & {$[0.113]$} & [0.043] & {$[0.031]$} & {$[0.073]$} & [0.044] & [0.078] & {$[0.040]$} & {$[0.147]$} & {$[0.147]$} & {$[0.054]$} \\
\hline EZ10p1 & $\begin{array}{l}0.121 \\
{[0.083]}\end{array}$ & $\begin{array}{l}0.209^{\star *} \\
{[0.092]}\end{array}$ & $\begin{array}{l}0.081^{\star *} \\
{[0.037]}\end{array}$ & $\begin{array}{l}0.029 \\
{[0.027]}\end{array}$ & $\begin{array}{l}-0.093 \\
{[0.068]}\end{array}$ & $\begin{array}{l}0.097^{\star *} \\
{[0.048]}\end{array}$ & $\begin{array}{l}-0.019 \\
{[0.062]}\end{array}$ & $\begin{array}{l}0.036 \\
{[0.033]}\end{array}$ & $\begin{array}{l}0.148 \\
{[0.150]}\end{array}$ & $\begin{array}{l}0.148 \\
{[0.150]}\end{array}$ & $\begin{array}{l}0.089^{\star} \\
{[0.047]}\end{array}$ \\
\hline EZ10p2 & $\begin{array}{l}0.163^{\star \star} \\
{[0.077]}\end{array}$ & $\begin{array}{l}0.154^{\star} \\
{[0.086]}\end{array}$ & $\begin{array}{l}0.192^{\star \star \star} \\
{[0.037]}\end{array}$ & $\begin{array}{l}0.084^{\star \star \star \star} \\
{[0.028]}\end{array}$ & $\begin{array}{l}-0.015 \\
{[0.063]}\end{array}$ & $\begin{array}{l}0.111^{\star *} \\
{[0.046]}\end{array}$ & $\begin{array}{l}-0.001 \\
{[0.068]}\end{array}$ & $\begin{array}{l}0.095^{\star \star \star} \\
{[0.035]}\end{array}$ & $\begin{array}{l}0.489^{\star \star \star} \\
{[0.157]}\end{array}$ & $\begin{array}{l}0.489^{\star \star \star} \\
{[0.157]}\end{array}$ & $\begin{array}{l}0.105^{\star *} \\
{[0.047]}\end{array}$ \\
\hline EZ01p1 & $\begin{array}{l}0.282^{*} \\
{[0.152]}\end{array}$ & $\begin{array}{l}0.298^{\star} \\
{[0.165]}\end{array}$ & $\begin{array}{l}0.108^{\star \star \star} \\
{[0.041]}\end{array}$ & $\begin{array}{l}0.145^{\star \star \star} \\
{[0.036]}\end{array}$ & $\begin{array}{l}0.212^{\star \star \star} \\
{[0.072]}\end{array}$ & $\begin{array}{l}0.059 \\
{[0.048]}\end{array}$ & $\begin{array}{l}0.129^{\star} \\
{[0.069]}\end{array}$ & $\begin{array}{l}0.017 \\
{[0.039]}\end{array}$ & $\begin{array}{l}0.189 \\
{[0.152]}\end{array}$ & $\begin{array}{l}0.189 \\
{[0.152]}\end{array}$ & $\begin{array}{l}0.144^{* *} \\
{[0.069]}\end{array}$ \\
\hline EZ01p2 & $\begin{array}{l}0.406^{\star \star \star} \\
{[0.123]}\end{array}$ & $\begin{array}{l}0.445^{\star \star \star} \\
{[0.155]}\end{array}$ & $\begin{array}{l}0.188^{\star \star \star} \\
{[0.043]}\end{array}$ & $\begin{array}{l}0.131^{\star \star \star} \\
{[0.034]}\end{array}$ & $\begin{array}{l}0.215^{\star \star \star} \\
{[0.068]}\end{array}$ & $\begin{array}{l}0.153^{\star \star \star} \\
{[0.046]}\end{array}$ & $\begin{array}{l}0.311^{\star \star \star} \\
{[0.072]}\end{array}$ & $\begin{array}{l}0.021 \\
{[0.041]}\end{array}$ & $\begin{array}{l}0.490^{\star * *} \\
{[0.134]}\end{array}$ & $\begin{array}{l}0.490^{\star \star \star} \\
{[0.134]}\end{array}$ & $\begin{array}{l}0.238^{\star \star \star} \\
{[0.065]}\end{array}$ \\
\hline Observations & 4161 & 4161 & 4161 & 4161 & 4161 & 4161 & 4161 & 4161 & 4161 & 4161 & 4161 \\
\hline Panels & 380 & 380 & 380 & 380 & 380 & 380 & 380 & 380 & 380 & 380 & 380 \\
\hline R-squared & 0.07 & 0.07 & 0.19 & 0.35 & 0.24 & 0.28 & 0.21 & 0.44 & 0.11 & 0.11 & 0.18 \\
\hline
\end{tabular}

OLS, robust standard errors in brackets

* significant at $10 \%$; ** significant at $5 \%$; *** significant at $1 \%$

Country pair fixed effects

Controls for capacity (=total sector/industry exports), industry specific real exchange rates, deviations from trend GDP and common year effects

$\begin{array}{ll}26 & \text { OTHER NON-METALLIC MINERAL PRODUCTS } \\ 27 & \text { BASIC METALS } \\ 28 & \text { FABRICATED METAL PRODUCTS, except machinery and equipment } \\ 29 & \text { MACHINERY AND EQUIPMENT, N.E.C. } \\ 30 & \text { OFFICE, ACCOUNTING AND COMPUTING MACHINERY } \\ 31 & \text { ELECTRICAL MACHINERY AND APPARATUS, NEC } \\ 32 & \text { RADIO, TELEVISION AND COMMUNICATION EQUIPMENT } \\ 33 & \text { MEDICAL, PRECISION AND OPTICAL INSTRUMENTS } \\ 34 & \text { MOTOR VEHICLES, TRAILERS AND SEMI-TRAILERS } \\ 35 & \text { OTHER TRANSPORT EQUIPMENT } \\ 36 & \text { FURNITURE; MANUFACTURING, N.E.C. }\end{array}$




\section{CESifo Working Paper Series}

(for full list see www.cesifo-group.de)

1820 Jan K. Brueckner and Raquel Girvin, Airport Noise Regulation, Airline Service Quality, and Social Welfare, October 2006

1821 Sijbren Cnossen, Alcohol Taxation and Regulation in the European Union, October 2006

1822 Frederick van der Ploeg, Sustainable Social Spending in a Greying Economy with Stagnant Public Services: Baumol's Cost Disease Revisited, October 2006

1823 Steven Brakman, Harry Garretsen and Charles van Marrewijk, Cross-Border Mergers \& Acquisitions: The Facts as a Guide for International Economics, October 2006

1824 J. Atsu Amegashie, A Psychological Game with Interdependent Preference Types, October 2006

1825 Kurt R. Brekke, Ingrid Koenigbauer and Odd Rune Straume, Reference Pricing of Pharmaceuticals, October 2006

1826 Sean Holly, M. Hashem Pesaran and Takashi Yamagata, A Spatio-Temporal Model of House Prices in the US, October 2006

1827 Margarita Katsimi and Thomas Moutos, Inequality and the US Import Demand Function, October 2006

1828 Eytan Sheshinski, Longevity and Aggregate Savings, October 2006

1829 Momi Dahan and Udi Nisan, Low Take-up Rates: The Role of Information, October 2006

1830 Dieter Urban, Multilateral Investment Agreement in a Political Equilibrium, October 2006

1831 Jan Bouckaert and Hans Degryse, Opt In Versus Opt Out: A Free-Entry Analysis of Privacy Policies, October 2006

1832 Wolfram F. Richter, Taxing Human Capital Efficiently: The Double Dividend of Taxing Non-qualified Labour more Heavily than Qualified Labour, October 2006

1833 Alberto Chong and Mark Gradstein, Who's Afraid of Foreign Aid? The Donors' Perspective, October 2006

1834 Dirk Schindler, Optimal Income Taxation with a Risky Asset - The Triple Income Tax, October 2006 
1835 Andy Snell and Jonathan P. Thomas, Labour Contracts, Equal Treatment and WageUnemployment Dynamics, October 2006

1836 Peter Backé and Cezary Wójcik, Catching-up and Credit Booms in Central and Eastern European EU Member States and Acceding Countries: An Interpretation within the New Neoclassical Synthesis Framework, October 2006

1837 Lars P. Feld, Justina A.V. Fischer and Gebhard Kirchgaessner, The Effect of Direct Democracy on Income Redistribution: Evidence for Switzerland, October 2006

1838 Michael Rauscher, Voluntary Emission Reductions, Social Rewards, and Environmental Policy, November 2006

1839 Vincent Vicard, Trade, Conflicts, and Political Integration: the Regional Interplays, November 2006

1840 Erkki Koskela and Mikko Puhakka, Stability and Dynamics in an Overlapping Generations Economy under Flexible Wage Negotiation and Capital Accumulation, November 2006

1841 Thiess Buettner, Michael Overesch, Ulrich Schreiber and Georg Wamser, Taxation and Capital Structure Choice - Evidence from a Panel of German Multinationals, November 2006

1842 Guglielmo Maria Caporale and Alexandros Kontonikas, The Euro and Inflation Uncertainty in the European Monetary Union, November 2006

1843 Jan K. Brueckner and Ann G. Largey, Social Interaction and Urban Sprawl, November 2006

1844 Eytan Sheshinski, Differentiated Annuities in a Pooling Equilibrium, November 2006

1845 Marc Suhrcke and Dieter Urban, Are Cardiovascular Diseases Bad for Economic Growth?, November 2006

1846 Sam Bucovetsky and Andreas Haufler, Preferential Tax Regimes with Asymmetric Countries, November 2006

1847 Luca Anderlini, Leonardo Felli and Andrew Postlewaite, Should Courts always Enforce what Contracting Parties Write?, November 2006

1848 Katharina Sailer, Searching the eBay Marketplace, November 2006

1849 Paul De Grauwe and Pablo Rovira Kaltwasser, A Behavioral Finance Model of the Exchange Rate with Many Forecasting Rules, November 2006

1850 Doina Maria Radulescu and Michael Stimmelmayr, ACE vs. CBIT: Which is Better for Investment and Welfare?, November 2006 
1851 Guglielmo Maria Caporale and Mario Cerrato, Black Market and Official Exchange Rates: Long-Run Equilibrium and Short-Run Dynamics, November 2006

1852 Luca Anderlini, Leonardo Felli and Andrew Postlewaite, Active Courts and Menu Contracts, November 2006

1853 Andreas Haufler, Alexander Klemm and Guttorm Schjelderup, Economic Integration and Redistributive Taxation: A Simple Model with Ambiguous Results, November 2006

1854 S. Brock Blomberg, Thomas DeLeire and Gregory D. Hess, The (After) Life-Cycle Theory of Religious Contributions, November 2006

1855 Albert Solé-Ollé and Pilar Sorribas-Navarro, The Effects of Partisan Alignment on the Allocation of Intergovernmental Transfers. Differences-in-Differences Estimates for Spain, November 2006

1856 Biswa N. Bhattacharyay, Understanding the Latest Wave and Future Shape of Regional Trade and Cooperation Agreements in Asia, November 2006

1857 Matz Dahlberg, Eva Mörk, Jørn Rattsø and Hanna Ågren, Using a Discontinuous Grant to Identify the Effect of Grants on Local Taxes and Spending, November 2006

1858 Ernesto Crivelli and Klaas Staal, Size and Soft Budget Constraints, November 2006

1859 Jens Brøchner, Jesper Jensen, Patrik Svensson and Peter Birch Sørensen, The Dilemmas of Tax Coordination in the Enlarged European Union, November 2006

1860 Marcel Gérard, Reforming the Taxation of Multijurisdictional Enterprises in Europe, "Coopetition" in a Bottom-up Federation, November 2006

1861 Frank Blasch and Alfons J. Weichenrieder, When Taxation Changes the Course of the Year - Fiscal Year Adjustments and the German Tax Reform 2000/2001, November 2006

1862 Hans Jarle Kind, Tore Nilssen and Lars Sørgard, Competition for Viewers and Advertisers in a TV Oligopoly, November 2006

1863 Bart Cockx, Stéphane Robin and Christian Goebel, Income Support Policies for PartTime Workers: A Stepping-Stone to Regular Jobs? An Application to Young LongTerm Unemployed Women in Belgium, December 2006

1864 Sascha O. Becker and Marc-Andreas Muendler, The Effect of FDI on Job Separation, December 2006

1865 Christos Kotsogiannis and Robert Schwager, Fiscal Equalization and Yardstick Competition, December 2006

1866 Mikael Carlsson, Stefan Eriksson and Nils Gottfries, Testing Theories of Job Creation: Does Supply Create Its Own Demand?, December 2006 
1867 Jacques H. Drèze, Charles Figuières and Jean Hindriks, Voluntary Matching Grants Can Forestall Social Dumping, December 2006

1868 Thomas Eichner and Marco Runkel, Corporate Income Taxation of Multinationals and Unemployment, December 2006

1869 Balázs Égert, Central Bank Interventions, Communication and Interest Rate Policy in Emerging European Economies, December 2006

1870 John Geweke, Joel Horowitz and M. Hashem Pesaran, Econometrics: A Bird's Eye View, December 2006

1871 Hans Jarle Kind, Marko Koethenbuerger and Guttorm Schjelderup, Taxation in TwoSided Markets, December 2006

1872 Hans Gersbach and Bernhard Pachl, Cake Division by Majority Decision, December 2006

1873 Gunther Schnabl, The Evolution of the East Asian Currency Baskets - Still Undisclosed and Changing, December 2006

1874 Horst Raff and Michael J. Ryan, Firm-Specific Characteristics and the Timing of Foreign Direct Investment Projects, December 2006

1875 Jukka Pirttilä and Håkan Selin, How Successful is the Dual Income Tax? Evidence from the Finnish Tax Reform of 1993, December 2006

1876 Agnieszka Stążka, Sources of Real Exchange Rate Fluctuations in Central and Eastern Europe - Temporary or Permanent?, December 2006

1877 Xavier Calsamiglia, Teresa Garcia-Milà and Therese J. McGuire, Why do Differences in the Degree of Fiscal Decentralization Endure?, December 2006

1878 Natacha Gilson, How to be Well Shod to Absorb Shocks? Shock Synchronization and Joining the Euro Zone, December 2006

1879 Scott Alan Carson, Modern Health Standards for Peoples of the Past: Biological Conditions by Race in the American South, 1873 - 1919, December 2006

1880 Peter Huber, Michael Pfaffermayr and Yvonne Wolfmayr, Are there Border Effects in the EU Wage Function?, December 2006

1881 Harry Flam and Håkan Nordström, Euro Effects on the Intensive and Extensive Margins of Trade, December 2006 